\section{Proteomic Analysis Using 2-D Liquid Separations of Intact Proteins From Whole-Cell Lysates}

This unit describes procedures for 2-D liquid separations of proteins from whole-cell lysates. Protocols for protein isoelectric point (pI) fractionation in the first dimension include the use of liquid isoelectric focusing (IEF; see Basic Protocol 1) and chromatofocusing (see Basic Protocol 2). The liquid IEF provides a pI-based fractionation using a batch-phase electrophoretic method, while chromatofocusing uses a column-based chromatographic method to generate the $\mathrm{pH}$ gradient. With either method, a second-dimension fractionation is provided in the liquid phase using nonporous silica-based reversed-phase HPLC (NPS-RP-HPLC; see Basic Protocol 3) to generate a 2-D liquid map of the protein content of the cell. Procedures for HPLC separation of the $\mathrm{pI}$ fractions of intact proteins are also described. The eluate of the 2-D liquid fractionation is directly coupled to a mass spectrometer for on-line detection of the intact molecular weights (MW) of proteins. As a result, a multidimensional map of protein expression is obtained that characterizes cellular proteins by $\mathrm{pI}$, hydrophobicity, and intact molecular weight. Such expression maps are useful for differential proteomic comparison between different cell samples.

\section{PROTEIN FRACTIONATION BY ISOELECTRIC FOCUSING USING THE ROTOFOR CELL}

The first dimension of the 2-D liquid separations presented in this unit is based upon isoelectric point $(\mathrm{pI})$ fractionation carried out in a manner analogous to 2-D gel electrophoresis (UNIT 10.4). In this protocol, pI fractionation is achieved by liquid phase isoelectric focusing (IEF). There are several ways to accomplish liquid-phase IEF (see UNIT 10.2 for general principles of IEF), including the use of carrier ampholytes, isoelectric membranes, and continuous flow electrophoresis (UNIT 22.5). In the present discussion, procedures are described for carrier ampholyte-based liquid IEF separations, which are analogous to separations using carrier ampholyte gels (Scopes, 1994). Liquid IEF has the advantages of high sample capacity, ability to fractionate over a broad $\mathrm{pH}$ range, and ability to separate cytosolic proteins in addition to membrane-bound proteins and proteins of high molecular weight.

The liquid-phase IEF separation is performed using a commercial device called the Rotofor (Bio-Rad). The Rotofor separates proteins in solution based on $\mathrm{pI}$, which is the $\mathrm{pH}$ value at which the net charge of a protein is zero. The amino acid sequence and the environment determine the charge on the protein. A protein is positively charged when the $\mathrm{pH}$ of the environment is lower than its $\mathrm{pI}$ and negatively charged when the $\mathrm{pH}$ of the environment is higher than its $\mathrm{pI}$. Upon application of electric potential, positively charged proteins move toward the anode and negatively charged proteins move toward the cathode until they are neutral, i.e., the pI is approached (See Fig. 23.3.1). Thus, the proteins are focused at their respective pIs. If the proteins attempt to diffuse out of their focused zones, they will ionize and the electric field will push them back to their pI.

This protocol describes a typical Rotofor experiment including materials and step-by-step separation procedures. The procedures are similar for the mini-Rotofor and standard Rotofor. With the following protocol, a wide range of protein samples can be fractionated into $20 \mathrm{pI}$ fractions over a range of $\mathrm{pH} 3$ to 12 using the standard commercial apparatus. In addition, these experiments have been devised to be compatible with a second dimension of liquid separation and further analysis by mass spectrometry.

Contributed by Kan Zhu, Fang Yan, Kimberly A. O’Neil, Rick Hamler, Linda Lin, Timothy J. Barder, and David M. Lubman

Current Protocols in Protein Science (2003) 23.3.1-23.3.28

Copyright $(\odot 2003$ by John Wiley \& Sons, Inc.
UNIT 23.3

BASIC

PROTOCOL 1

Non-Gel-Based

Proteome Analysis

23.3.1

Supplement 34 


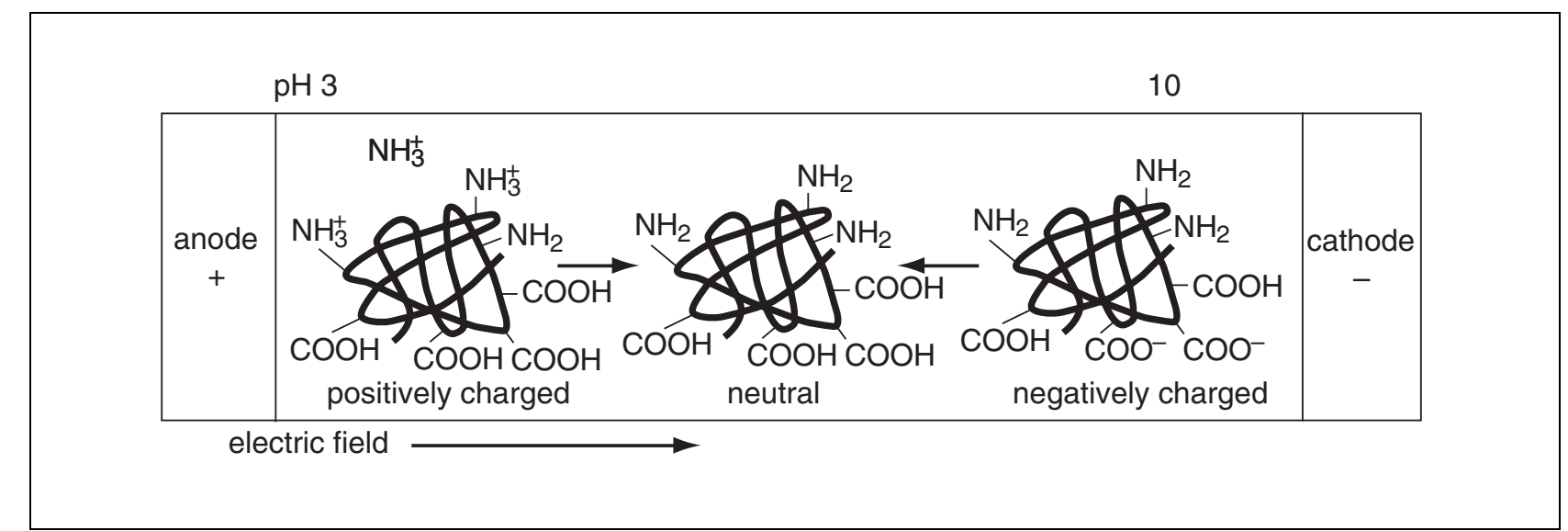

Figure 23.3.1 Electrophoretic focusing in the Rotofor. Denaturing conditions are utilized for isoelectric focusing, so proteins will not be present in their native folded states as depicted here.

To obtain optimum performance with the Rotofor, it is necessary to quantify proteins from cell lysates before the Rotofor fractionation. Each collected pI fraction should also be analyzed quantitatively for protein to calculate overall recovery. The Bradford assay is a convenient method of protein quantitation, considering its compatibility with many detergents, chaotropes, and reducing agents. However, some reducing reagents and detergents may interfere with the assay. Check the compatible reagent lists that accompany the assay kits before using.

The sample concentration must be within the linear range of the standard curve, from 1.2 to $10 \mu \mathrm{g} / \mathrm{ml}$ (for Bradford microassay). A dilution from 40 to 400 is usually performed for cell lysates and fractionated samples. In order to eliminate the possible interference from the cell lysis buffer or running buffer, the same volume of corresponding buffer is mixed with dye, standard, and water and analyzed as a blank.

\section{Materials}

Protein sample: see e.g., Support Protocol 1; concentration determined, e.g., by Bradford assay (UNIT 3.4) or Bio-Rad RC-DC Protein Assay Kit

Cathode electrolyte: $0.1 \mathrm{M} \mathrm{NaOH}$

Anode electrolyte: $0.1 \mathrm{M} \mathrm{H}_{3} \mathrm{PO}_{4}$

Rotofor running buffer (see recipe)

Bio-Lyte 3/10 ampholyte (Bio-Rad)

Rotofor system (Bio-Rad)

Circulating water cooling system

Power supply with constant power capability

50-ml conical centrifuge tube

50-ml syringe with 19-G, 1.5-in. needle

Harvesting tubes: $12 \times 75$-mm culture tubes

Cold trap

Vacuum pump

$\mathrm{pH}$ meter

Additional reagents and equipment for protein assay (UNIT 3.4)

2-D Liquid

Separations of

Whole-Cell Lysates

23.3.2 
1. Equilibrate anion-exchange membrane in $0.1 \mathrm{M} \mathrm{NaOH}$ and cation-exchange membrane in $0.1 \mathrm{M} \mathrm{H}_{3} \mathrm{PO}_{4}$ overnight.

Ion-exchange membranes isolate the electrolytes from the focusing chamber while allowing current to flow. Anion- and cation-exchange membranes are not interchangeable. Once they are wet, they should be kept in cathode and anode electrolyte solution, respectively.

2. Assemble the Rotofor system according to the manual.

The standard Rotofor and mini-Rotofor have different sets of membrane cores and focusing chambers. The standard Rotofor holds $60 \mathrm{ml}$ and can handle milligram to grams of total protein, while the mini-Rotofor can hold $18 \mathrm{ml}$ and is more appropriate for micrograms to milligrams of total protein.

3. Connect circulation water and power supply to the Rotofor system.

The cooling system is important for heat dissipation. The two ports on the cooling finger are interchangeable.

4. Seal the harvesting port of the Rotofor with sealing tape. Fill the Rotofor chamber with distilled water, then seal the loading port with tape. Apply $5 \mathrm{~W}$ for $5 \mathrm{~min}$, then remove the tape and discard the water.

This is a necessary step to remove residual ionic contaminants from the membrane core and the ion-exchange membranes.

\section{Load sample and begin run}

5. Seal the harvesting port with tape. Before loading, mix the protein sample with the Rotofor running buffer in a 50-ml conical centrifuge tube for a total volume of $18 \mathrm{ml}$ (for Mini-Rotofor), making sure that the final concentration of ampholytes matches that of the protein, per Table 23.3.1. Load the sample/running buffer mixture into the Rotofor chamber using a 50-ml syringe with a 19-G, 1.5-in. needle, taking care that no air bubbles are trapped. Seal the loading port with tape.

During filling, air bubbles can be trapped in the system, especially with the mini-Rotofor. This will cause fluctuations in voltage and discontinuity in the electric field. Bubbles must be removed before the separation starts (see Troubleshooting). Gloves should be worn when handling the tape; otherwise skin keratins may contaminate samples.

6. Apply $12 \mathrm{~W}$ (mini-Rotofor) or $15 \mathrm{~W}$ (standard Rotofor) of constant power to the chamber (current decreases with time while voltage increases), maintaining the temperature at $\sim 15^{\circ} \mathrm{C}$ by setting the coolant temperature to $4^{\circ} \mathrm{C}$.

The separation process takes about $4 \mathrm{hr}$ and is complete when the voltage remains stable for $\sim 30 \mathrm{~min}$.

When potential is applied to the sample solution, charged proteins and carrier ampholytes move toward their pI values, so that the initial current is high. With the increase of time, carrier ampholytes and some of the proteins reach their pIs and are neutralized, so that the number of charged species decreases and the current decreases with time. Do not wait too long after the voltage is stable; otherwise, the established $\mathrm{pH}$ gradient will collapse.

Table 23.3.1 Ampholyte Concentration Corresponding to Sample Concentration ${ }^{a}$

\begin{tabular}{ll}
\hline Protein concentration & Ampholytes (v/v) \\
\hline$>2 \mathrm{mg} / \mathrm{ml}$ & $2 \%$ \\
$1 \mathrm{mg} / \mathrm{ml}$ & $1.5 \%$ \\
$0.5 \mathrm{mg} / \mathrm{ml}$ & $1 \%$ \\
$0.25 \mathrm{mg} / \mathrm{ml}$ & $0.5 \%$ \\
\hline
\end{tabular}

${ }^{a}$ This information was taken from the Bio-Rad Rotofor instruction manual.

Non-Gel-Based Proteome Analysis

23.3.3

Supplement 34 
ALTERNATE PROTOCOL 1

2-D Liquid

Separations of

Whole-Cell Lysates

23.3.4

\section{Harvest fractionated sample}

7. Place 20 harvesting tubes into the rack inside the harvest box. Connect the outlet of the harvest box with the cold trap that is connected to a vacuum pump. Start vacuum pump.

The cold trap is used to protect the vacuum pump and is not supplied with the Rotofor system. A typical glass cold trap contains one inlet, which is connected to the outlet of the harvesting box, and one outlet, which is connected to the vacuum pump.

8. Turn the power supply off and disconnect it. Remove the tape from the loading port and punch the 20 pins through the tape on the harvesting ports.

Focused fractions are aspirated from the focusing chamber by the vacuum pump. To prevent uneven harvesting, make sure needles are pushed uniformly through the sealing tape into the chamber. These procedures need to be performed quickly and without shaking the apparatus, so that diffusion of proteins after removal of the electric field is minimized.

9. Measure $\mathrm{pH}$ of the 20 collected fractions with a $\mathrm{pH}$ meter (Fig. 23.3.2). Determine protein concentration of each fraction (UNIT 3.4 or Bio-Rad RC-DC Protein Assay kit).

The fractions are now ready for a second-dimension separation, e.g., see Basic Protocol 3. If the samples are not used right after fractionation, they should be stored frozen at $-80^{\circ} \mathrm{C}$. It is best to analyze them within 6 months.

10. Disassemble and clean the Rotofor system. Clean the ion-exchange membranes with distilled water, detergent (e.g., $\sim 10 \%$ Alconox), or $0.1 \mathrm{M} \mathrm{NaOH}$ to remove residual proteins and then place them back into fresh equilibration solution (see step 1).

The membranes are reusable if kept wet. The membrane core should also be thoroughly washed with distilled water and is reusable.

\section{AMPHOLYTE-FREE PREPARATIVE ISOELECTRIC FOCUSING OVER NARROW pH RANGES IN THE ROTOFOR CELL}

\section{Additional Materials (also see Basic Protocol 1)}

Rotolyte buffer-pair mixtures (Bio-Rad)

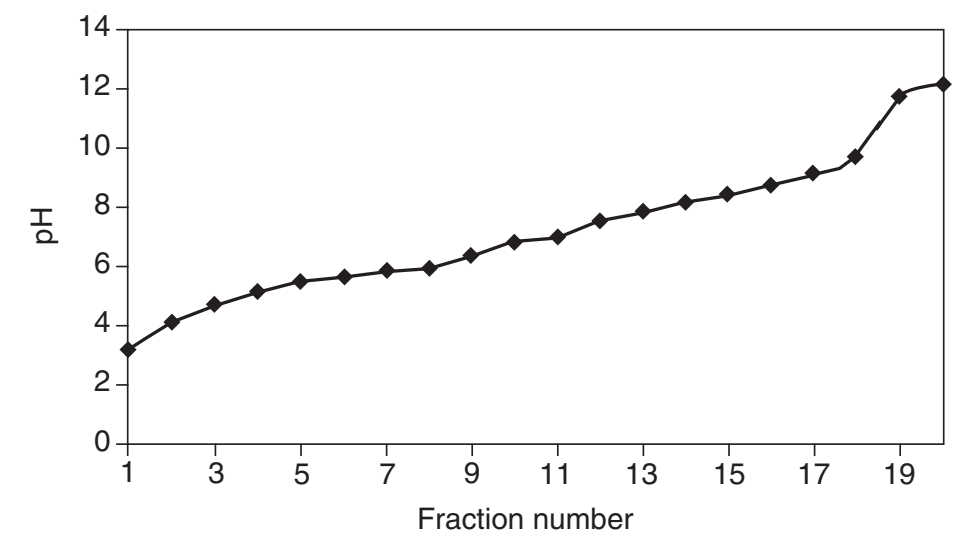

Figure 23.3.2 A typical pH gradient achieved in a Rotofor experiment. 
In Basic Protocol 1, the $\mathrm{pH}$ gradient is maintained by thousands of ampholytes. In this ampholyte-free method, only one of 13 buffer pairs is used at a time. When voltage is applied, the buffer pair generates a $\mathrm{pH}$ gradient between the individual $\mathrm{pK}_{\mathrm{a}}$ values of the buffers. The simple mixture of the buffer pair cannot provide as wide a linear range as the ampholyte-based method; the typical $\mathrm{pH}$ range used in this method is within 1 to 2 $\mathrm{pH}$ units. This is a useful method for concentrating a limited number of proteins over a small $\mathrm{pH}$ range, but is not suitable for profiling proteins in a complex biosystem. The method eliminates possible interferences from ampholytes, thereby extending its applicability to protein samples incompatible with ampholytes.

The thirteen buffer pairs used in this method are listed in the Bio-Rad Rotofor manual. This series of buffer pairs cover the $\mathrm{pH}$ range from $\mathrm{pH} 2.9$ to 11.0. Prior to the experiment, the $\mathrm{pI}$ of the target proteins should be known. For optimum resolution, ratios of the selected buffer pairs can be adjusted so that the $\mathrm{pI}$ of the protein to be purified falls near the middle of the established $\mathrm{pH}$ gradient.

The experimental procedure here is essentially the same as that for the ampholyte-based method (see Basic Protocol 1). However, the running buffer and electrolytes used in the anodic and cathodic cells are different. The running buffer is usually composed of 50\% (v/v) water/sample and 50\% (v/v) Rotolyte buffer-pair mixtures. A high concentration of buffer mixtures is important for preventing $\mathrm{pH}$ distortion when charged proteins migrate. Anode and cathode electrolytes are categorized in the Bio-Rad Rotolyte instruction manual. Appropriate electrolytes should be used to minimize the $\mathrm{pH}$ distortion at the acidic and basic ends.

\section{ISOELECTRIC FOCUSING USING THE ROTOFOR WITH ION-EXCHANGE RESIN AS ELECTROLYTE}

\section{Additional Materials (also see Basic Protocol 1)}

AG50W-X8 cation exchanger (hydrogen form; Bio-Rad)

AG1-X8 anion exchange resin (hydroxide form; Bio-Rad)

One of the limitations of the Rotofor is the $\mathrm{pH}$ gradient distortion at the acidic and basic ends. During electrophoresis, ampholytes and proteins migrate and focus at their pI points in the chamber; however, in the anode and cathode cells, gas generated during electrolysis pushes acid and base through the ion-exchange membranes and into the focusing chamber. Using ion-exchange resins in both electrodes where free hydronium and hydroxide ions are in equilibrium with ions attached to the resin can alleviate this problem. The result is that a limited number of free ions are pushed through the membrane and the $\mathrm{pH}$ gradient distortion is minimized.

In this alternative procedure, the focusing experiment is conducted in the same manner as described in Basic Protocol 1; however, instead of loading $0.1 \mathrm{M}$ phosphoric acid in the anode and $0.1 \mathrm{M}$ sodium hydroxide in the cathode, AG50W-X8 cation exchanger (hydrogen form) and AG1-X8 anion exchange resin (hydroxide form) are applied to the anode and cathode, respectively. Prior to the experiment, the resin should be washed with deionized water three times, after which it should be resuspended in deionized water for a volume of $\sim 20 \mathrm{ml}$, drawn up into a 50-ml syringe without a needle, and injected into the electode cell until the cell is $\sim 80 \%$ full. When using resins in the electrode chambers, Rotofor running times can be greatly increased as compared to the standard operating conditions.

Non-Gel-Based

Proteome Analysis

23.3.5

Supplement 34 
Chromatofocusing (CF; also see UNIT 8.5) has been used as an alternative method for performing a pI separation in the first dimension of the 2-D liquid separation scheme (Sluyterman, 1978; Sluyterman, 1981a,b; Liu and Anderson, 1997; Strong and Frey, 1997; Fountoulakis et al., 1998; Hutchens, 1998; Chong et al., 2001). CF is a column-based chromatographic method that uses a weak anion exchange column to generate a descending linear $\mathrm{pH}$ gradient. In contrast to conventional ion exchange chromatography, the exchanger is titrated using ampholytes (Polybuffer, Amersham Pharmacia Biotech) rather than salts as the titration media. The result is a $\mathrm{pH}$ separation where fractionation can be performed down to $<0.1 \mathrm{pH}$ units. The $\mathrm{CF}$ method has been marketed for many years by Amersham Pharmacia Biotech and is used mainly as a preparative method to purify a limited number of proteins for further chromatographic analysis (Pharmacia Biotech, 1985). However, with recent proprietary advances in ion-exchange column technology and polyampholyte buffers, this method has demonstrated the capability of fractionating large numbers of proteins from mammalian cell lysates as the first step in a 2-D liquid chromatography setup. This improved 2-D column technology is available through Eprogen, Inc., under the name ProteoSep 2-D Protein Mapping Kit.

In the $\mathrm{CF}$ process, $\mathrm{pH}$ is monitored using an on-line $\mathrm{pH}$ probe mounted in a flow cell; consequently, each $\mathrm{pH}$ range can be automatically collected using a fraction collector. The use of CF allows efficient interfacing to the second-dimension NPS-RP-HPLC (see Basic Protocol 3) separation without additional sample manipulation. The use of on-line $\mathrm{pH}$ monitoring also provides a basis for reproducibly collecting $\mathrm{pH}$ fractions from different samples. A second dimension such as NPS-RP-HPLC can then be used to analyze each $\mathrm{pI}$ fraction. The result is a 2-D UV map of protein expression, with high reproducibility. Furthermore, this technique provides excellent fractionation and relatively pure proteins in the liquid phase that can be collected for further characterization. The method below has a protein loading capacity comparable to 2-D gels, i.e., between $100 \mu \mathrm{g}$ and $5 \mathrm{mg}$. Most importantly, the use of CF as the first dimension of separation allows the entire 2-D liquid separation process to be readily automated.

\section{Materials}

Protein sample: see, e.g., Support Protocol 1; concentration determined, e.g., by Bradford assay UNIT 3.4 or Bio-Rad RC-DC Protein Assay kit

$\mathrm{CF}$ start buffer (see recipe for $\mathrm{pH}$ ranges 8.5 to 4 or 7 to 4 )

$\mathrm{CF}$ elution buffer (see recipe for $\mathrm{pH}$ ranges 8.5 to 4 or 7 to 4 )

\section{$1 \mathrm{M} \mathrm{NaCl}$}

Desalting column: PD-10 (Sephadex G-25; Amersham Pharmacia Biotech)

NPS-RP-HPLC column (recommended): $33 \times 4.6-\mathrm{mm}$ Micra Platinum column (Eprogen)

HPLC/FPLC system running at ambient temperature and at a flow rate of 0.2 $\mathrm{ml} / \mathrm{min}$, with fraction collector, UV detector $(280 \mathrm{~nm}), \mathrm{pH}$ electrode, flow cell, and flow meter

Chromatofocusing (CF) column: HPCF 1-D column (Eprogen)

Additional reagents and equipment for desalting and buffer exchange by column chromatography (UNIT 8.3)

NOTE: The CF buffers (see Reagents and Solutions for recipes) bracket the $\mathrm{pH}$ range over which the separation is to be performed. CF Buffer solutions are also commercially available through Eprogen as part of the 2-D Proteosep kit. It is preferable to use the

2-D Liquid Separations of Whole-Cell Lysates

23.3.6 
Exchange samples into CF start buffer

1. Equilibrate the PD-10 column with $\sim 25 \mathrm{ml}$ of CF start buffer (also see UNIT 8.3).

2. Load $2.5 \mathrm{ml}$ of sample onto PD-10 column (if the sample volume is $<2.5 \mathrm{ml}$, bring to volume with CF start buffer). Discard the eluate.

3. Add $3.5 \mathrm{ml}$ of CF start buffer to the PD-10 column after the sample has entered the column bed. Collect the eluate until all $3.5 \mathrm{ml}$ of the buffer has entered the bed.

\section{Test sample preparation on RP-HPLC column (recommended)}

4. Inject $50 \mu \mathrm{l}$ of exchanged sample onto a NPS-RP-HPLC column to check the detailed reversed-phase elution profile of the sample prior to $\mathrm{pI}$ fractionation.

This second-dimension RP-HPLC analysis is highly recommended prior to running the first-dimension CF analysis. If any sample preparation problems have occurred, they will be readily identified after analysis of the chromatogram from this step. This diagnostic measure may also help the investigator extend the lifetime of the column, since the distribution of the hydrophobicities of proteins can be obtained in the prerun. More hydrophobic proteins will elute from the column later, and if there are more hydrophobic proteins in the sample, extensive cleaning is required for the CF and reversed-phase columns to extend their lifetime.

Depending on the complexity and amount of proteins expected to be in the sample, a very "spiky"-or "porcupine"-looking chromatogram (Fig. 23.3.3) should be obtained at this point. One should not proceed to the CF fractionation step if one does not see a protein profile that makes sense for the sample being analyzed.

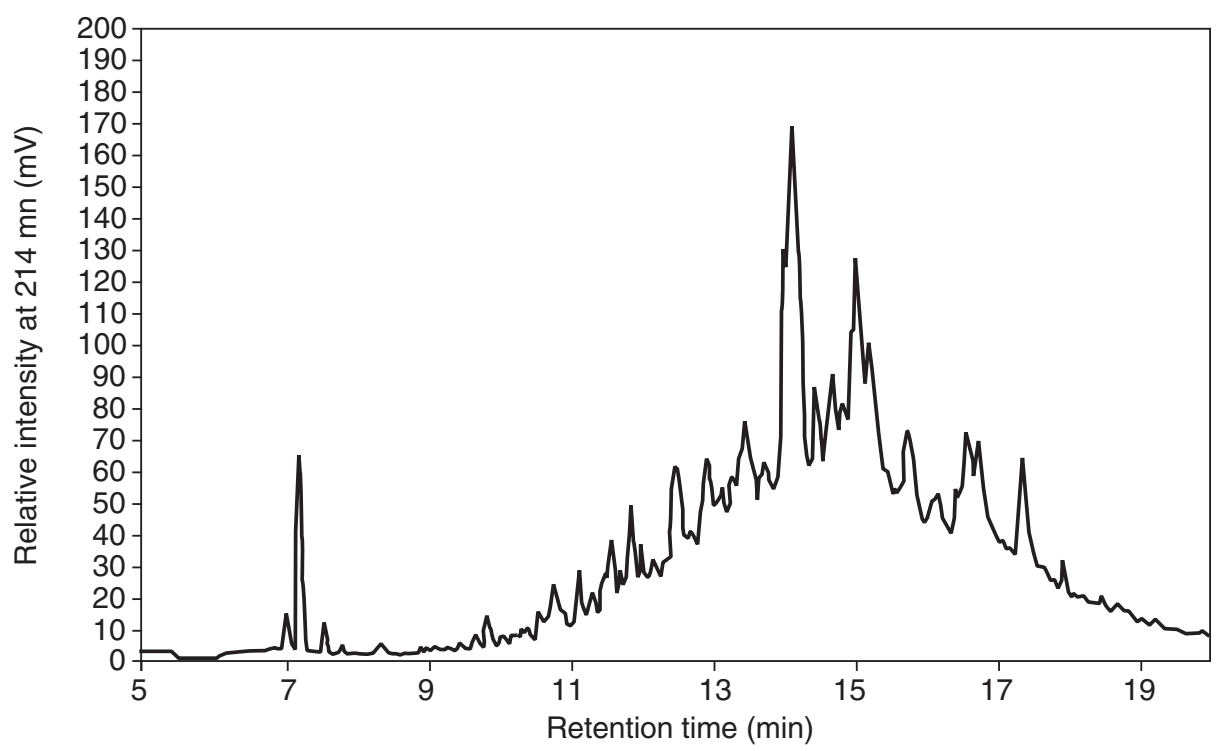

Figure 23.3.3 Chromatogram of hepatocyte cell culture sample exchanged with start buffer (optional pre-run on second-dimension NPS-RP column, without previous CF; see Basic Protocol 2, step 4).

Non-Gel-Based Proteome Analysis

23.3.7

Supplement 34 
Perform first-dimension analysis by chromatofocusing

5. Before injection, flush the CF column with 10 column volumes $(\mathrm{CV}$; for the HPCF 1 -D column, $1 \mathrm{CV}=0.87 \mathrm{ml}$ ) of $100 \%$ distilled water, filtered with a $0.45-\mu \mathrm{m}$ filter.

6. Equilibrate the $\mathrm{CF}$ column with $100 \% \mathrm{CF}$ start buffer until the $\mathrm{pH}$ of the effluent reaches that of the start buffer and the baseline is stable $(\sim 30 \mathrm{CV})$.

7. Inject 1.0 to $3.0 \mathrm{ml}$ of sample onto the $\mathrm{CF}$ column.

Loading 1 to $5 \mathrm{mg}$ of total protein is recommended to allow for UV detection of lowerabundance proteins. With injections of 10 to $100 \mu \mathrm{g}$ of total protein, it is possible to obtain a separation of highly expressed proteins, but proteins expressed in low abundance will not be readily observed using $U V$ detection. The number of proteins observed is related to the total protein load, the concentration of the individual protein, and the UV absorption detection of the protein. When studying samples that contain a dominant protein (e.g., serum or urine), loading on the high end of the recommended total protein amount ( 1 to 5 mg) may cause overload of the UV signal in the pI fraction where the dominant protein elutes.

8. Wash CF column with $100 \%$ CF start buffer at a flow rate of $0.2 \mathrm{ml} / \mathrm{min}$ while monitoring the baseline absorbance.

Collect this wash as a single fraction since all proteins with pIs $>8.5$ will elute from the column during this wash step. After the UV absorbance value returns to baseline, stop the flow of start buffer. The wash step will take 10 to $30 \mathrm{~min}$.

9. Before beginning the $\mathrm{pH}$ gradient, flush the tubing and pump head with $100 \%$ elution buffer (volume depending on system configuration) to reduce dead volume. Start the gradient by running $100 \%$ elution buffer at $0.2 \mathrm{ml} / \mathrm{min}$. Allow 65 to $70 \mathrm{~min}$ to perform the full $\mathrm{pH}$ gradient; at $\sim 60 \mathrm{~min}$ the $\mathrm{pH}$ of the eluate should be $4.0 \pm 0.1$. Collect fractions at chosen $\mathrm{pI}$ intervals, generally 0.1 to $0.3 \mathrm{pH}$ units, using fraction collector. Monitor and record the $\mathrm{pH}$ at the start and end of each fraction collected.

Software for automatic monitoring of the $\mathrm{pH}$ and reproducible fraction collection has been developed by Dr. Steven J. Parus (sparus@umich.edu) of the University of Michigan, Department of Chemistry.

2-D Liquid

Separations of

Whole-Cell

Lysates

23.3.8

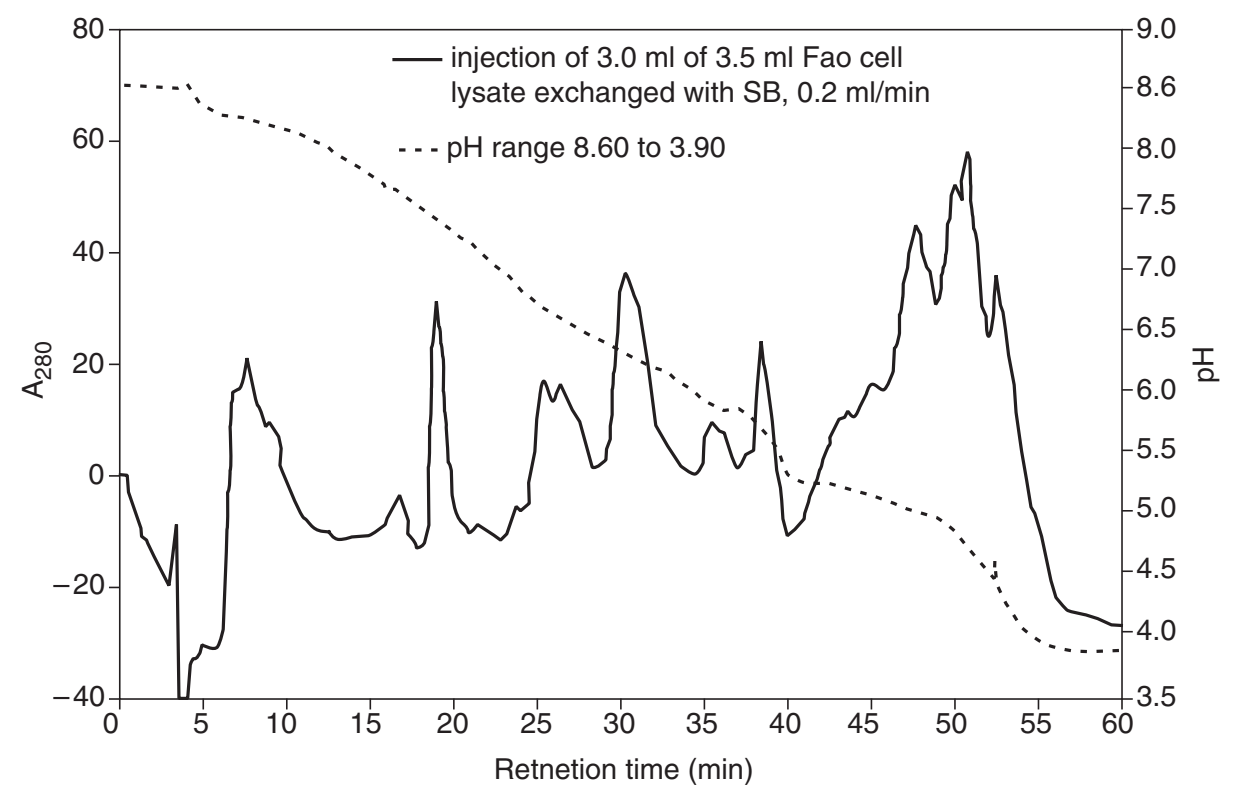

Figure 23.3.4 UV profile of a typical chromatofocusing experiment. 
10. After completing $\mathrm{pH}$ run, wash $\mathrm{HPCF}$ column with $10 \mathrm{CV}$ of $1.0 \mathrm{M} \mathrm{NaCl}$. Collect the UV peak(s) as a fraction for analysis with the second-dimension column (see e.g., Fig. 23.3.4).

11. Transfer fractions from the fraction collector that are to be analyzed in the second dimension to appropriate vials for use with the HPLC autosampler. Freeze fractions at $-20^{\circ} \mathrm{C}$ or below if the second dimension analysis is not to be performed within 8 to $10 \mathrm{hr}$.

Basic Protocol 3 provides an example of a second-dimension separation.

12. Wash the $\mathrm{CF}$ column with $10 \mathrm{CV}$ of deionized water.

The HPCF 1-D column can be stored in water at room temperature up to 1 to 2 days, but should be stored in 100\% isopropanol for long periods of time ( $>2$ days) at room temperature.

\section{CELL LYSIS FOR PROTEIN FRACTIONATION BY CHROMATOFOCUSING OR ISOELECTRIC FOCUSING USING THE ROTOFOR}

Cell lysis is a process that extracts proteins from cells. In order to keep extracted proteins intact in solution, the $\mathrm{pH}$ of the lysis buffer is controlled close to physiological $\mathrm{pH}$ using Tris buffer, and proteases are inhibited by protease inhibitors. Furthermore, various nonionic chaotropes, detergents, and reducing reagents can be used to enhance the solubility of proteins. In both the electrophoretic-based separation (liquid-phase IEF, Rotofor) and the ion-exchange-based separation (chromatofocusing), the ions will cause the focusing and protein binding, respectively, to deteriorate so maintaining low ionic strength is a key issue.

\section{Materials}

Cells for analysis

$50 \mathrm{mM}$ Tris. $\mathrm{Cl}, \mathrm{pH} 7.8$ to 8.2 (APPENDIX 2E; any $\mathrm{pH}$ between these values can be used) containing $1 \mathrm{mM}$ PMSF (add from $0.5 \mathrm{M}$ stock in DMSO or isopropanol; see note below)

General lysis buffer (see recipe)

Membrane lysis buffers A and B (see recipes)

$0.1 \mathrm{M}$ sodium carbonate (ice cold)

$50 \mathrm{mM}$ Tris.Cl, pH 7.3 (APPENDIX 2E) containing $1 \mathrm{mM}$ PMSF (add from $0.5 \mathrm{M}$ stock in DMSO or isopropanol; see note below)

Ultrasonicator with microtip probe (e.g., Branson; for bacterial lysis)

Bath sonicator (for membrane lysis)

Centrifuge (refrigerated centrifuge capable of $20,000 \times g$ for general lysis procedure; ultracentrifuge capable of $150,000 \times g$ for membrane lysis procedure)

Dry ice/acetone bath

NOTE: PMSF has a half-life in aqueous solution of $\sim 1 \mathrm{hr}$. Therefore, a stock solution of $0.5 \mathrm{M}$ PMSF should be made in DMSO or isopropanol and should be added to the aqueous lysis solutions ( $50 \mathrm{mM}$ Tris. $\mathrm{Cl}$ and membrane lysis buffer A) to a final concentration of $0.5 \mathrm{mM}$ (i.e., half the original concentration of $1 \mathrm{mM}$ ) every hour. The DMSO or isopropanol stock can be stored at $4^{\circ} \mathrm{C}$ for up to 1 month.

CAUTION: Be aware that PMSF is highly toxic and solutions containing this compound must be handled with caution at all times.

Non-Gel-Based Proteome Analysis

23.3.9

Supplement 34 


\section{For bacterial cells}

1a. Suspend the 10-mg bacterial cell pellet in $0.4 \mathrm{ml}$ of $50 \mathrm{mM}$ Tris. $\mathrm{Cl}, \mathrm{pH} 7.8$ to 8.2. Vortex vigorously, then sonicate using an ultrasonicator with a microtip in an ice bath. Repeat this procedure twice, each time for $30 \mathrm{sec}$, to break the cell membranes.

2a. Mix the suspension into $1.6 \mathrm{ml}$ of general lysis buffer.

The final cell lysate consists of $6 \mathrm{M}$ urea, $2 \mathrm{M}$ thiourea, $10 \%$ glycerol, $50 \mathrm{mM}$ Tris, $2 \%$ $O G L, 5 \mathrm{mM}$ TCEP, and $1 \mathrm{mM}$ protease inhibitor.

3a. Centrifuge solution at $>20,000 \times g$ for $60 \mathrm{~min}$.

4a. Remove the supernatant from the cell debris. Store at $-20^{\circ} \mathrm{C}$ until use.

This sonication method works well for most Gram-negative bacteria such as E. coli. It may not work well for Gram-positive bacteria and other specialized bacteria with strong cell membranes. In these cases, it is recommended to use a much more rigorous method to break the cell membrane, such as the French press (UNITS $6.1 \& 6.7$ ).

\section{For human cell lines}

1b. Mix $\sim 0.4 \mathrm{ml}$ of a single-cell suspension of cell line sample containing $1 \times 10^{8}$ cells into $1.6 \mathrm{ml}$ of general lysis buffer and vortex vigorously. If cells are in pellet form, suspend the cell pellet in $0.4 \mathrm{ml}$ of $50 \mathrm{mM}$ Tris. $\mathrm{Cl}$, $\mathrm{pH} 7.8$ to 8.2 , and vortex, then add $1.6 \mathrm{ml}$ of general lysis buffer and vortex vigorously.

The final cell lysate consists of: $6 \mathrm{M}$ urea, $2 \mathrm{M}$ thiourea, $10 \%$ glycerol, $50 \mathrm{mM}$ Tris, $2 \%$ OGL, $5 \mathrm{mM}$ TCEP, $1 \mathrm{mM}$ of protease inhibitor.

2b. Centrifuge the lysate $60 \mathrm{~min}$ at $>20,000 \times g, 4^{\circ} \mathrm{C}$.

3b. Remove the supernatant from the cell debris. Store at $-20^{\circ} \mathrm{C}$ until use.

\section{For membrane protein lysis}

1c. Suspend cell pellet equivalent to $6 \times 10^{8}$ cells in $3 \mathrm{ml}$ of membrane lysis buffer $\mathrm{A}$. Vortex vigorously.

2c. Lyse cells by placing tubes in an dry ice/acetone bath to quickly freeze cells, then allowing them to thaw at room temperature. Vortex thoroughly and freeze again. Repeat this cycle a total of five times. Sonicate in a bath sonicator on ice for $30 \mathrm{~min}$, then vortex again.

3c. Repeat step 2c two additional times for a total of 15 freeze/thaws and three sonications.

4c. Centrifuge $20 \mathrm{~min}$ at $2800 \times g, 4^{\circ} \mathrm{C}$, to remove unlysed cells. Remove supernatant and set aside on ice.

5c. Resuspend the pellet from step $4 \mathrm{c}$ in $1 \mathrm{ml}$ of membrane lysis buffer A, repeat steps $2 \mathrm{c}$ to $4 \mathrm{c}$, and pool the resulting supernatant with that set aside in step $4 \mathrm{c}$.

6c. Add 10 volumes of $0.1 \mathrm{M}$ sodium carbonate to the pooled supernatant. Agitate/stir on ice for $1 \mathrm{hr}$.

7c. Collect membranes by centrifuging $1 \mathrm{hr}$ at $150,000 \times g, 4^{\circ} \mathrm{C}$. Remove and discard supernatant.

8c. Resuspend pellet by adding $1 \mathrm{ml}$ of $50 \mathrm{mM}$ Tris. $\mathrm{Cl}, \mathrm{pH} 7.3$, and vortexing. Collect membranes by centrifuging for $1 \mathrm{hr}$ at $150,000 \times \mathrm{g}, 4^{\circ} \mathrm{C}$. Remove and discard supernatant. Repeat this wash step two more times for a total of three washes of the membrane pellet.

This serves to remove soluble protein contaminants in the membrane preparation. 
9c. Solubilize the membrane pellet in $1.2 \mathrm{ml}$ of membrane lysis buffer B and vortex vigorously until pellet dissolves. Use more buffer if necessary for solubilization. Store at $-20^{\circ} \mathrm{C}$ until use.

This membrane extraction procedure isolates all cellular membranes including the plasma membrane as well as organelle membranes such as mitochondria, Golgi, and vesicles.

\section{NONPOROUS REVERSED-PHASE CHROMATOGRAPHY INTERFACED TO ESI-MS}

Reversed-phase chromatography (RP-HPLC; also see UNITS $8.7 \& 11.6$ ) is a widely used separation method with powerful resolving capability, reproducibility, and recovery. Separation in RP-HPLC is based on hydrophobicity; thus, it serves as an orthogonal separation method to the first-dimension pI separation. In RP-HPLC, after a protein sample has adsorbed to the column material, a gradient of increasingly hydrophobic mobile phase causes a protein molecule to elute from the column when its affinity for the mobile phase exceeds its affinity for the stationary phase. When the organic concentration in the mobile phase reaches a particular value, the protein desorbs from the stationary phase and enters the mobile phase to elute from the column. Hydrophobic proteins interact more strongly with the bonded stationary phase (conventionally alkyl groups such as $\mathrm{C} 4$, $\mathrm{C} 8$, and C18) than hydrophilic proteins and, consequently, elute from the column later during the separation. Under optimal conditions, protein peak retention times vary only approximately $0.1 \mathrm{~min}$ (Wall, 2000, 2001; Kachman, 2002) over a total separation time of $30 \mathrm{~min}$ for complex protein sample mixtures. High reproducibility of retention times using nonporous silica (NPS) columns permits collection of protein peaks for further analysis, including peptide mass fingerprinting using MALDI-MS (Chong et al., 1999; Wall et al., 1999; Chong et al., 2000; UNIT 16.5). In addition, this technique permits comparison of chromatographic profiles for differential proteomic studies.

\section{Strategic Planning for Interfacing NPS RP-HPLC to ESI-MS}

\section{Electrospray ionization}

Electrospray ionization (ESI) is an ideal interface between RP-HPLC and mass spectrometry (MS). The HPLC eluate can be directly introduced on-line to the ESI source. Eluate solution is sprayed through a capillary with high voltage applied, producing multiply charged droplets. The charges are dispersed on the droplet surface until the charge-charge repulsion exceeds the surface tension, forcing the droplet to split into smaller droplets. Heated desolvation gas in the ESI source aids in decreasing droplet size by vaporizing solvent molecules, causing greater charge repulsion and droplet instability. This process continues until all solvent has evaporated and the sample molecules become multiply charged gas-phase ions. ESI is a soft ionization method where proteins are detected as intact, multiply charged molecular ions with little or no fragmentation. Since proteins possess multiple sites capable of accepting protons, the mass spectrum appears as an umbrella of multiply charged ions. The intact molecular weight (MW) of the protein is obtained by deconvoluting the multiply charged peaks in the ESI-MS spectrum (see Fig. 23.3.5).

\section{Desalting}

Fractions from the $\mathrm{pH}$ dimension contain reagents other than proteins. Chaotropes, detergents, and ampholyte molecules can both interfere with and suppress sample ionization and detection. They suppress ionization of sample molecules by competing for charges. In addition, the large number of ionized reagent species may saturate the mass spectrometer detector and decrease the signal-to-noise ratio of detection (Cech and Enke, 2001). Detergents and metal ions can form adducts with proteins, leading to the detection of artifactual protein modifications. Therefore, desalting before ESI-MS is necessary to
BASIC PROTOCOL 3

Non-Gel-Based Proteome Analysis

23.3.11

Supplement 34 
obtain high-sensitivity spectra without adducts or other artifacts. RP-HPLC provides an excellent means of sample desalting, since proteins can be concentrated onto the head of the column and remain on the column during a water wash. Multiple injections of deionized water are used to wash off various unwanted reagents. The Rotofor fractions require more water injections for washing than chromatofocusing fractions, since there are more contaminants that need to be eliminated.

\section{Interfacing pH-separated fractions to NPS-RP-HPLC}

After $\mathrm{pH}$ fractionation, proteins remain in the liquid phase. Sample concentration and desalting are achieved on the RP column. Consequently, no further sample treatment is necessary for interfacing to the $\mathrm{pH}$ fractions to liquid chromatography. Considering the differences in sample capacity for the standard Rotofor, mini-Rotofor, and chromatofocusing, a protein assay (UNIT 3.4) is usually performed to quantify each fraction so that the optimal amount of protein is introduced onto RP column.

All $\mathrm{pH}$-separated fractions should be analyzed individually to maximize the separation capacity for both dimensions. The greater the number of fractions obtained in the

A

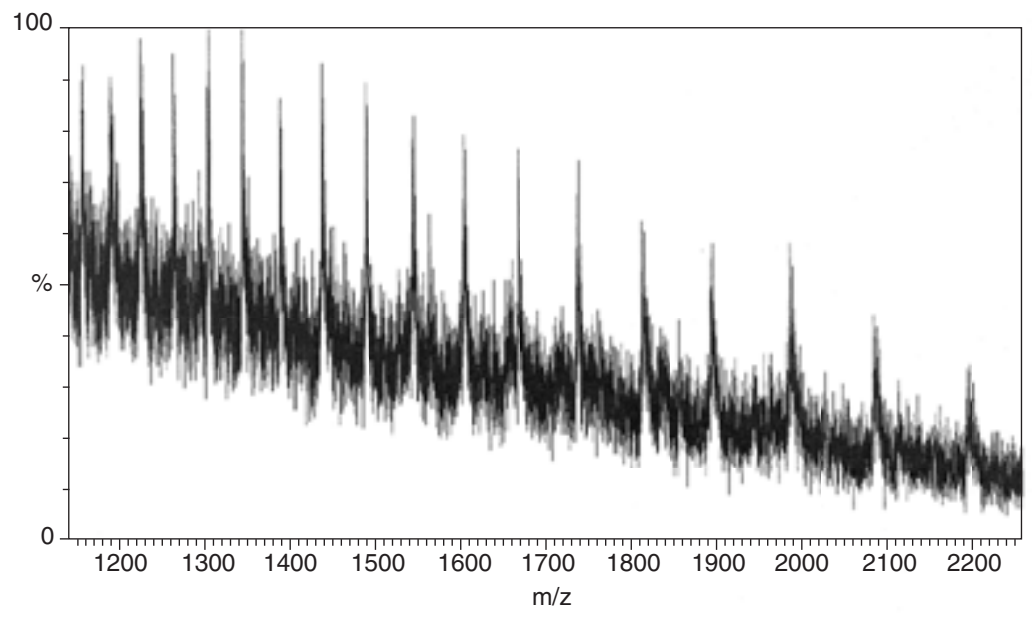

B

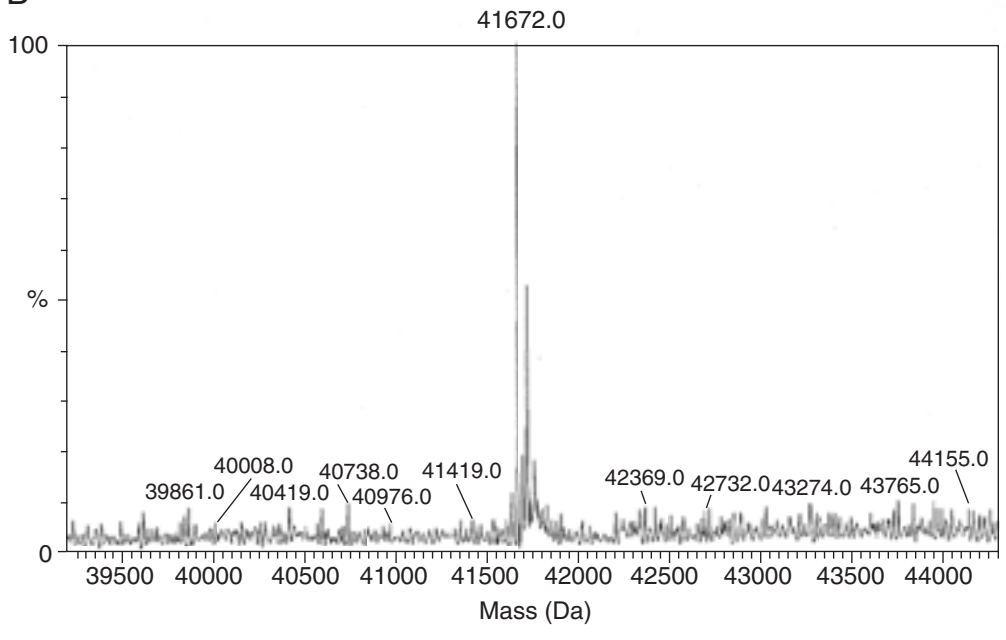

2-D Liquid

Separations of

Whole-Cell Lysates
Figure 23.3.5 NPS-RP-HPLC/ESI-TOF mass spectrum of $\beta$-actin and $\gamma$-actin. (A) Combined ESI-TOF spectra of $\beta$-actin and $\gamma$-actin. (B) MaxEnt deconvoluted $\beta$-actin and $\gamma$-actin. 
first-phase separation, the better the resolution achieved in the $\mathrm{pH}$ dimension and in the subsequent HPLC separation; however, the greater the number of fractions obtained, the greater the amount of work required in the second dimension. In the case of the Rotofor, up to 20 fractions are obtained in the first dimension. However, in CF, if one uses a $0.1-\mathrm{pH}$ unit fractionation, then up to 45 fractions may be obtained over the entire range, each of which needs to be interfaced to RP-HPLC.

The running conditions in the $\mathrm{pH}$ dimension are different from those in the RP-HPLC. In the $\mathrm{pH}$ dimension, proteins are focused to their $\mathrm{pI}$ values, where protein solubility is at a minimum, making chaotropes and detergents necessary to prevent protein precipitation. In RP-HPLC, the mobile phase $\mathrm{pH}$ is very acidic because of the addition of TFA and FA. Chaotropes and detergents are not necessary and are actually detrimental to the ESI process. The change in $\mathrm{pH}$ and medium may cause some protein precipitation. In order to prolong the lifetime of the RP column, it is necessary to mix the sample with mobile phase A (no organic modifier) to minimize precipitation and centrifuge the mixture at $14,000 \mathrm{rpm}$ for $10 \mathrm{~min}$ to eliminate particulates.

\section{Column selection}

In order to select an appropriate column for RP-HPLC, factors such as particle size, column diameter, pore size, and coating should be considered (Scopes, 1994). Decreasing particle size helps intraparticulate mass transfer and increases column efficiency and resolution. The major disadvantage is the increased back-pressure that accompanies the use of smaller particles at the same flow rate. However, at an acceptable working pressure, a smaller particle size provides improved separation. This protocol employs $1.5-\mu \mathrm{m}$ ODS(C18) nonporous silica (NPS) particles (Eprogen, Inc.). NPS columns provide a faster high-resolution separation with better protein recovery than comparable porous columns (Gooding and Regnier, 1990; Hanson et al., 1996; Banks and Gulcicek, 1997; Barder et al., 1997). Slow and restricted diffusion of protein molecules in conventional porous packing materials limits the speed of protein separation while maintaining satisfactory resolution and detection sensitivity. Moreover, recovery is low due to protein adsorption within pores in the stationary phase preventing protein elution. Considering the follow-up analysis with MS, high speed and efficiency are essential for several reasons. First, a high-speed separation results in less MS data to be processed and a subsequent gain in sample throughput. Also, ESI-MS is a concentration-sensitive technique; therefore, high efficiency in the RP-HPLC separation implies better sensitivity in MS separation (Niessen and Tinke, 1995). Nonporous media eliminate issues of macromolecular pore adsorption and stagnant mobile phase in the intraparticle void volume associated with porous stationary phases. As a result, higher column efficiency is obtained with much improved resolution (Chen and Horvath, 1995; Hanson et al., 1996; Lee, 1997; Yu and El Rassi, 1997; Yang and Lee, 1999). A disadvantage is decreased surface area, hence sample capacity, which is compensated for by using very small $(1.5-\mu \mathrm{m})$ silica particles. Decreasing the length of the column alleviates the problem of high back-pressure associated with small particles. In addition, at elevated temperatures, NPS packing materials are generally more stable than their porous counterparts. Overall, the high efficiency of NPS $1.5-\mu \mathrm{m}$ packing allows for reproducible, high resolution, high-speed protein separations.

In RP-HPLC, the surface of the stationary phase is hydrophobic. Rigid supports such as silica are covalently bonded with alkyl groups, typically $\mathrm{C} 4, \mathrm{C} 8$, and $\mathrm{C} 18$. The interaction between protein and the immobilized alkyl groups increases with longer alkyl chain. Although stationary phases with shorter alkyl chains have demonstrated better recovery, short-chain, polar, bonded-phase silica experiences poor stability in reversed-phase operation at the low $\mathrm{pH}$ and elevated temperature required for efficient protein separations

Non-Gel-Based Proteome Analysis

23.3.13

Supplement 34 
(Kastner, 2000). Consequently, C18 (ODS) stationary phase is still the choice for interfacing RP-HPLC to ESI-MS.

Small-diameter columns are more easily interfaced to ESI-MS because of their lower optimum flow rate; however, the sample capacity of narrow-bore columns is low. For regular columns, the optimum flow rate is usually too high $(\sim 1 \mathrm{ml} / \mathrm{min})$ to be efficiently ionized by ESI. Flow splitting after the column is necessary for effectively interfacing such columns ( $\geq 4.6 \mathrm{~mm}$ in diameter) with ESI-MS (Niessen and Tinke, 1995). The NPS 3 -mm diameter columns ( 33 or $53 \mathrm{~mm}$ in length) are optimal in these studies. The flow rates used are generally 0.2 to $0.4 \mathrm{ml} / \mathrm{min}$ through the column and 0.1 to $0.2 \mathrm{ml} / \mathrm{min}$ after the split.

There are three kinds of NPS columns: ODS-I, ODS-II, and ODS-IIIE, available through Eprogen. NPS ODS-I is polymeric bonded phase with low surface silanol activity and no silanol end capping. The stability over a broad $\mathrm{pH}$ range makes the ODS-I phase suitable for analyzing fractions in the range of $\mathrm{pH} 2$ to 10. NPS ODS-II phase is monomeric in nature; it provides a more hydrophilic surface and higher selectivity than the ODS-I phase for the protein separation (see volume 3 of the Eprogen manual for Micra HPLC columns; http://www.eprogen.com/hplc/catalog/cataloglowrez.pdf). It is the premium choice for the separation of proteins after CF fractionation due to its excellent peak shape, higher resolution, and peak capacity. However, the ODS-II stationary phase is not as stable as ODS-I within the basic $\mathrm{pH}$ range. The mobile phase $\mathrm{pH}$ for ODS-II is from $\mathrm{pH} 2$ to 9; ODS-I can go up to $\mathrm{pH} \mathrm{10,} \mathrm{but} \mathrm{for} \mathrm{storage,} \mathrm{it} \mathrm{is} \mathrm{better} \mathrm{to} \mathrm{keep} \mathrm{these} \mathrm{columns} \mathrm{between} \mathrm{pH}$ 5 and 9. ODS-IIIE has monomeric binding like ODS-II except it is end-capped, which provides faster separation for small molecules and high stability for basic species.

In order to select the right column for a separation, particle size, pressure, recovery, stability, sample capacity, and efficiency need to be balanced. The authors typically use NPS $1.5 \mu \mathrm{m}$-particle size packed columns. In the case of UV detection, generally, $4.6 \times$ $33-\mathrm{mm}$ columns have been used. When interfacing to ESI-MS, the $3 \times 33-\mathrm{mm}$ NPS columns have been used. In cases where large amounts of sample need to be collected for further analysis, an $8 \times 33-\mathrm{mm}$ column has been used with a flow rate of $1 \mathrm{ml} / \mathrm{min}$.

\section{Temperature control}

Protein separations require the use of elevated column temperatures to achieve good separation efficiency and reproducibility. At elevated temperatures, the mobile phase viscosity is reduced and mass transfer in solution is enhanced. High pressure due to the use of small-dimension packing materials is alleviated, allowing faster separations (Chen and Horvath, 1995). Moreover, at higher temperatures, the sorption kinetics of the sample are accelerated; as a result, plate height decreases and column efficiency increases.

Temperature can also affect protein structure and the reversed-phase surface. This could alter sample interaction with the reversed-phase surface and, as a result, resolution may be improved or degraded. Hence, stable temperature control is necessary for reproducible separation. In RP-HPLC, the use of an acidic hydro-organic mobile phase generally denatures proteins, so that using elevated temperatures does not further complicate the separation. One must be careful about using a temperature that is too high, where proteins may be labile. Furthermore, the stationary phase may not be stable at elevated temperatures. For RP-HPLC separations using nonporous silica, a column temperature of $60^{\circ}$ to $65^{\circ} \mathrm{C}$ is generally most effective. At this temperature, rapid, high-resolution separations are obtained on columns packed with $1.5 \mu \mathrm{m}$ NPS ODS without problems in column or protein stability.

2-D Liquid

Separations of

Whole-Cell Lysates

23.3.14

Supplement 34

Current Protocols in Protein Science 
In order to choose the organic component of the mobile phase, solute solubility, ionization efficiency, and miscibility of the eluent components should be considered. The eluting strength of the commonly used organic eluents follows the order: methanol<acetonitrile<ethanol<isopropanol. Acetonitrile has been used in this work because of its high volatility and low viscosity. ESI efficiency is related to solvent surface tension; a high surface tension requires high capillary voltage for ionization, and thus reduces efficiency. Acetonitrile is often chosen for its suitability in ESI-MS.

Although proteins are fractionated based on their $\mathrm{pI}$ values, not all proteins in the $\mathrm{pH}$ fractionated samples are neutral. Static interaction of charged proteins causes decreased resolution and recovery. To eliminate this interference, anionic ion-pair reagents such as trifluoroacetic acid (TFA) or cationic ion-pair reagents such as triethylammonium ions are added to the mobile phase. Solute ions and pairing ions form neutral complexes and adsorb to the stationary phase. Tetrabutylammonium salts, alkylsulfonates, TFA, formic acid (FA), phosphate buffer, and hydrochloric acid are all viable choices for ion-pairing reagents. TFA is most commonly used because of its volatility and compatibility with UV detection. Compared with TFA, the FA ion-pair system exhibits a lower degree of resolution. However, the use of an ion-pairing reagent suppresses analyte electrospray ionization (Mehlis and Kertscher, 1997). Considering that ESI ionization is a proton-binding process, the presence of excess protons in solution will alleviate the suppression. Formic acid is usually added to improve analyte ionization efficiency (Cech and Enke, 2001). Also, the detergent $n$-octyl- $\beta$-D-glucopyranoside (OGL) added to the RP separation improves recovery and resolution during separation; however, it ionizes well in ESI and interferes with sample peaks, causing problems in data analysis. Consequently, it is not used in NPS-RP-HPLC separations that are interfaced on-line with ESI-MS; however, it is used in separations where protein peaks are collected from the RP dimension for further analysis.

\section{Gradient}

Gradient elution is exclusively applied in separating proteins complexed with the liquid chromatography stationary phase. The complexity of the sample and the application determine gradient selection. In gradient elution, the average capacity factor is proportional to the gradient slope. The use of a steep, or fast, gradient results in a small average capacity factor and, hence, less separation. A shallow, or slow, gradient results in a large average capacity factor and, hence, more separation and better resolution. However, when interfacing with ESI-MS, additional factors need to be considered. A shallow gradient results in broader peaks with decreased peak height; as a result, there is decreased sensitivity since ESI-MS is a concentration-dependent detector.

Elution peaks are not evenly distributed over a chromatogram when a linear gradient is used. Most protein peaks elute from the column in the middle range of the gradient, $30 \%$ to $50 \%$, if acetonitrile is used as the organic modifier. In order to make full use of the peak capacity on liquid chromatography, a concave gradient, i.e., shallow in the middle and steep at the two ends, is usually applied (See Table 23.3.2).

Non-Gel-Based

Proteome Analysis

\subsubsection{5}

Supplement 34 
Table 23.3.2 A Sample Gradient for NPS-RP-HPLC Separation

\begin{tabular}{ll}
\hline Organic $(\% \mathrm{~B})$ & Duration $(\mathrm{min})$ \\
\hline $5-15$ & 1 \\
$15-25$ & 2 \\
$25-31$ & 3 \\
$31-41$ & 10 \\
$41-47$ & 3 \\
$47-67$ & 4 \\
$67-100$ & 1 \\
\hline
\end{tabular}

\section{Materials}

Sample fractions from $\mathrm{pH}$ separation (see Basic Protocol 1 or 2), with the protein concentration of each fraction determined (UNIT 3.4)

$100 \%$ acetonitrile

NPS-RP-HPLC Solvent A: dissolve $1 \mathrm{ml}$ trifluoroacetic acid (TFA) and $3 \mathrm{ml}$ formic acid (FA) in $996 \mathrm{ml}$ ultrapure water

NPS RP-HPLC Solvent B: Dissolve $1 \mathrm{ml}$ TFA and $3 \mathrm{ml} \mathrm{FA} \mathrm{in} 996 \mathrm{ml} \mathrm{HPLC}$-grade acetonitrile

HPLC system including:

HPLC Pump

RP column (NPS ODS-II, $3 \times 33.0 \mathrm{~cm}$; Eprogen)

Column heater

Splitter

Syringe

Ferrules

PEEK tubing

\section{Clean and equilibrate the system}

1. Purge the HPLC system with deionized water to remove salt.

Inorganic salts may precipitate in the organic solvent in the tubing and the column.

2. Equilibrate column by first washing with $100 \%$ acetonitrile for $180 \mathrm{~min}$ followed by several blank gradients (from $100 \%$ water to $100 \%$ acetonitrile).

Running a "blank gradient" means, specifically, that at a flow rate of $1 \mathrm{ml} / \mathrm{min}$, one should apply the same gradient that will be used in the sample separation and make sure that the baseline is stable. Typically, one blank gradient is enough, but sometimes two to three blank gradients may be necessary.

\section{Prepare and load sample}

3. Dilute samples with starting mobile phase (NPS RP-HPLC solvent A) and centrifuge $10 \mathrm{~min}$ at $25,000 \times \mathrm{g}$, room temperature, to remove any precipitated protein and other particulates.

Proper sample preparation is important to extend the lifetime of the column.

4. Remove the supernatant from the centrifuged sample and inject it onto the column. Wash the column with multiple injections of deionized water until a water peak is observed.

2-D Liquid

Separations of

Whole-Cell Lysates

23.3.16

The wash step is recommended to eliminate detergents and salts which can interfere with $M S$ analysis. When monitored at $214 \mathrm{~nm}$ with a UV detector, water absorption is lower than the mobile phase absorption, so injection of water will result in a negative peak. 


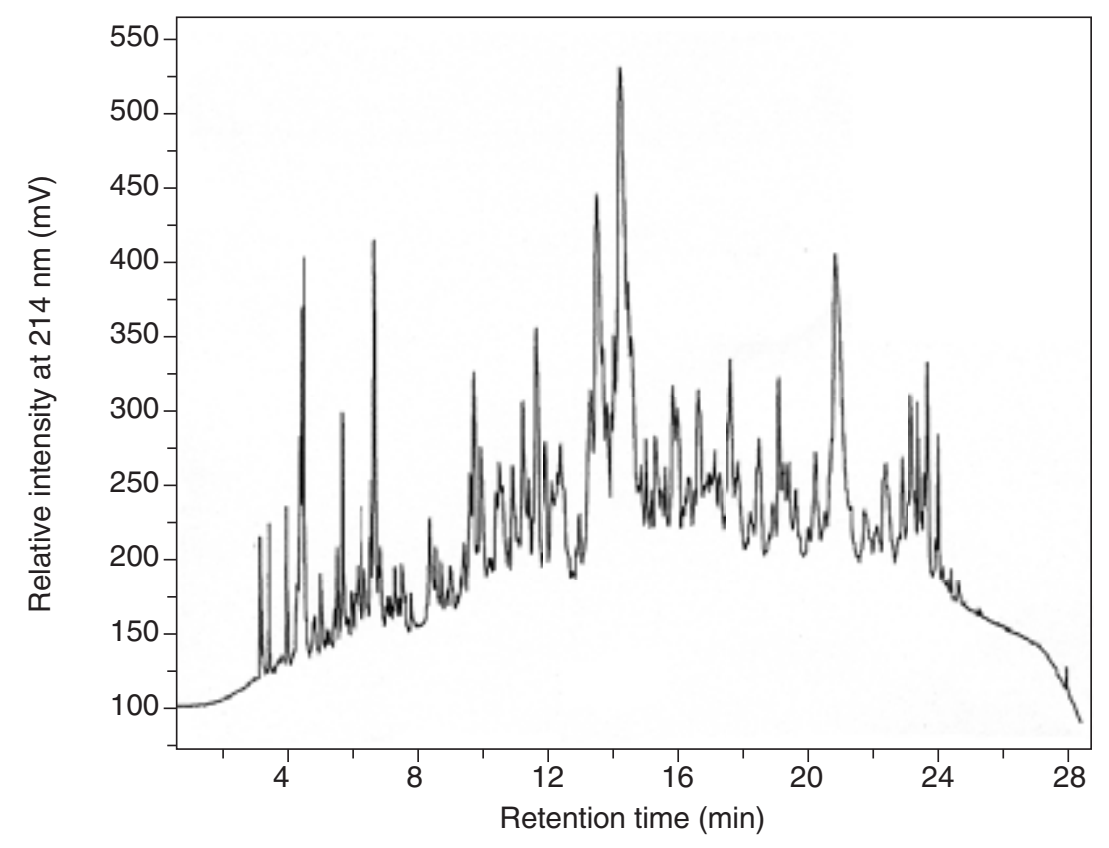

Figure 23.3.6 The NPS-RP-HPLC chromatogram of chromatofocusing fraction $\mathrm{pH} 5.27$ to 5.47 of colon cancer HCT116 cell line (UV $214 \mathrm{~nm}$ ).

\section{Prepare and optimize ESI-MS}

5. Adjust the splitter to make sure the flow to the ESI-MS is optimized.

Optimal results can be obtained when a 150 to $200 \mu \mathrm{l} / \mathrm{min}$ flow is introduced to the mass spectrometer. The rule of thumb is to make sure that the eluate vaporizes completely. An easy means to check this (for the Micromass LCT mass spectrometer) is to ensure that there is no liquid accumulating on the baffle which is positioned opposite to the electrospray capillary.

\section{Run NPS-RP-HPLC}

6. Start gradient and data collection (Fig. 23.3.6).

7. To regenerate the column, rinse with 5 column volumes of deionized water, run $100 \%$ NPS RP-HPLC solvent B through the column for $30 \mathrm{~min}$, then perform a sawtooth gradient for 20 cycles.

Column regeneration and cleaning is important for prolonging column lifetime and reproducible separation results. Some proteins tend to show memory effects, so a sawtooth gradient is recommended. Memory effects refer to phenomena whereby, because proteins elute at a certain acetonitrile percentage, they will not elute off the column until the same acetonitrile percentage is reached again. A sawtooth gradient is a fast gradient from $100 \%$ water to $100 \%$ acetonitrile, followed by a gradient from $100 \%$ acetonitrile to $100 \%$ water, within the same time. The process is repeated several times.

8. Analyze data (see Support Protocol 2).

Non-Gel-Based

Proteome Analysis

23.3.17 


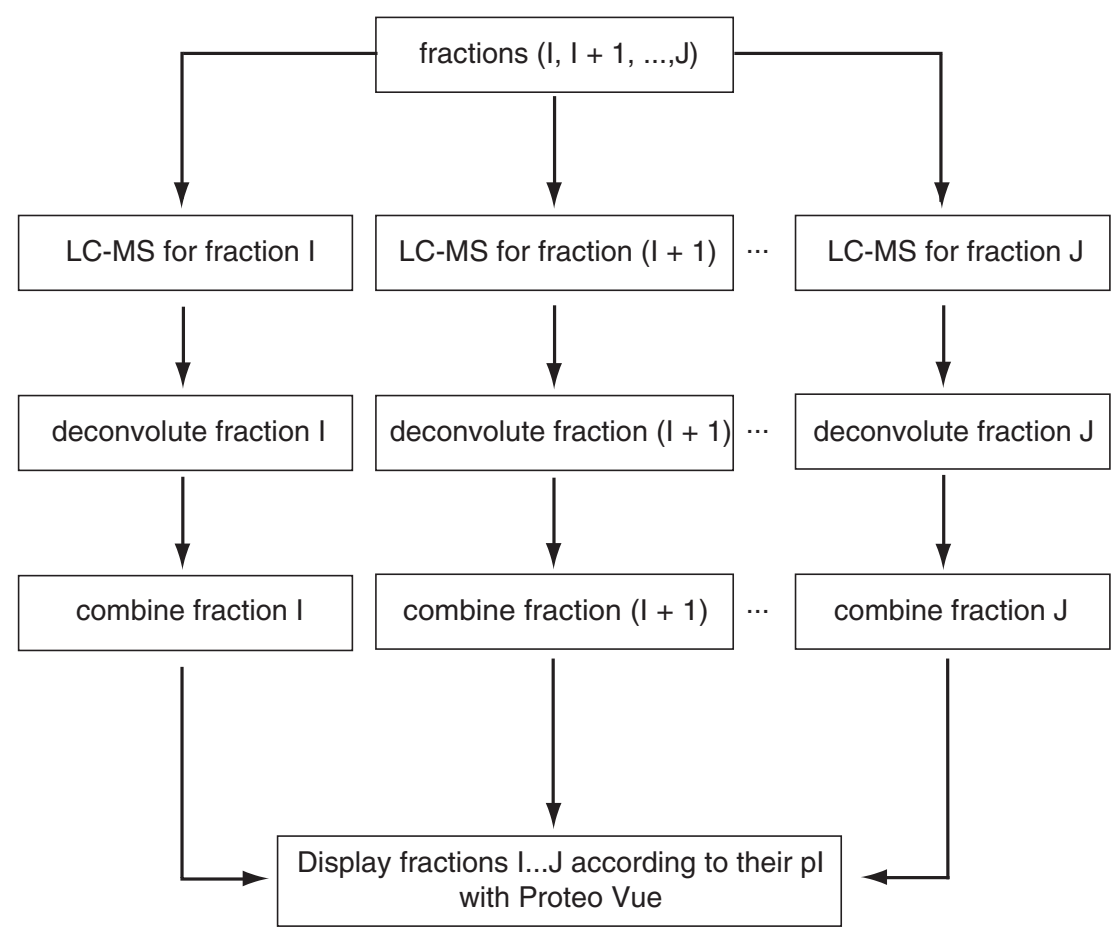

Figure 23.3.7 Flow chart of 2-D map data process.

\section{INTEGRATING PI, MW, AND ABUNDANCE INFORMATION INTO 2-D MAP}

As shown in Figure 23.3.7, fractions obtained from $\mathrm{pH}$-based separations are subjected to LC-MS. In order to construct a liquid-phase 2-D map, fractions within the target $\mathrm{pH}$ range (fractions I to J in Fig. 23.3.7) are each analyzed by LC-MS (see Basic Protocol 3). One such liquid-phase 2-D map is shown in Figure 23.3.8. After fractionation of the whole-cell lysate of MCF10A, which is a normal breast epithelial cell line, using the Rotofor cell, each of the 20 fractions are analyzed by LC-MS. The MW value and peak area information are obtained from each deconvolution and combined for each fraction. The combined data are displayed in parallel according to their $\mathrm{pH}$. A band on the 2-D map represents each protein, and its abundance is proportional to the optical density of the band. Bands with the same MW value in adjacent fractions with very close $\mathrm{pI}$ values may indicate an overlapping of a highly abundant protein; however, they are different proteins if their $\mathrm{pI}$ values are different. Furthermore, corresponding $\mathrm{pH}$ fractions from different samples are compared by placing resulting lane maps side by side (see Fig. 23.3.9).

In the LC-MS experiment, a mass spectrum is acquired every second, so a typical 30-min run generates a tremendous amount of information. In order to convert raw MS data (as shown in Fig. 23.3.5A) into protein MW (as in Fig. 23.3.5B), a large number of deconvolutions need to be performed to obtain quantitative data. Although deconvolution software programs such as MaxEnt (Micromass, available from Waters) extract MW information for complex protein mixtures, the deconvolution is a time-consuming process that currently limits the throughput.

2-D Liquid

Separations of

Whole-Cell Lysates

23.3.18 


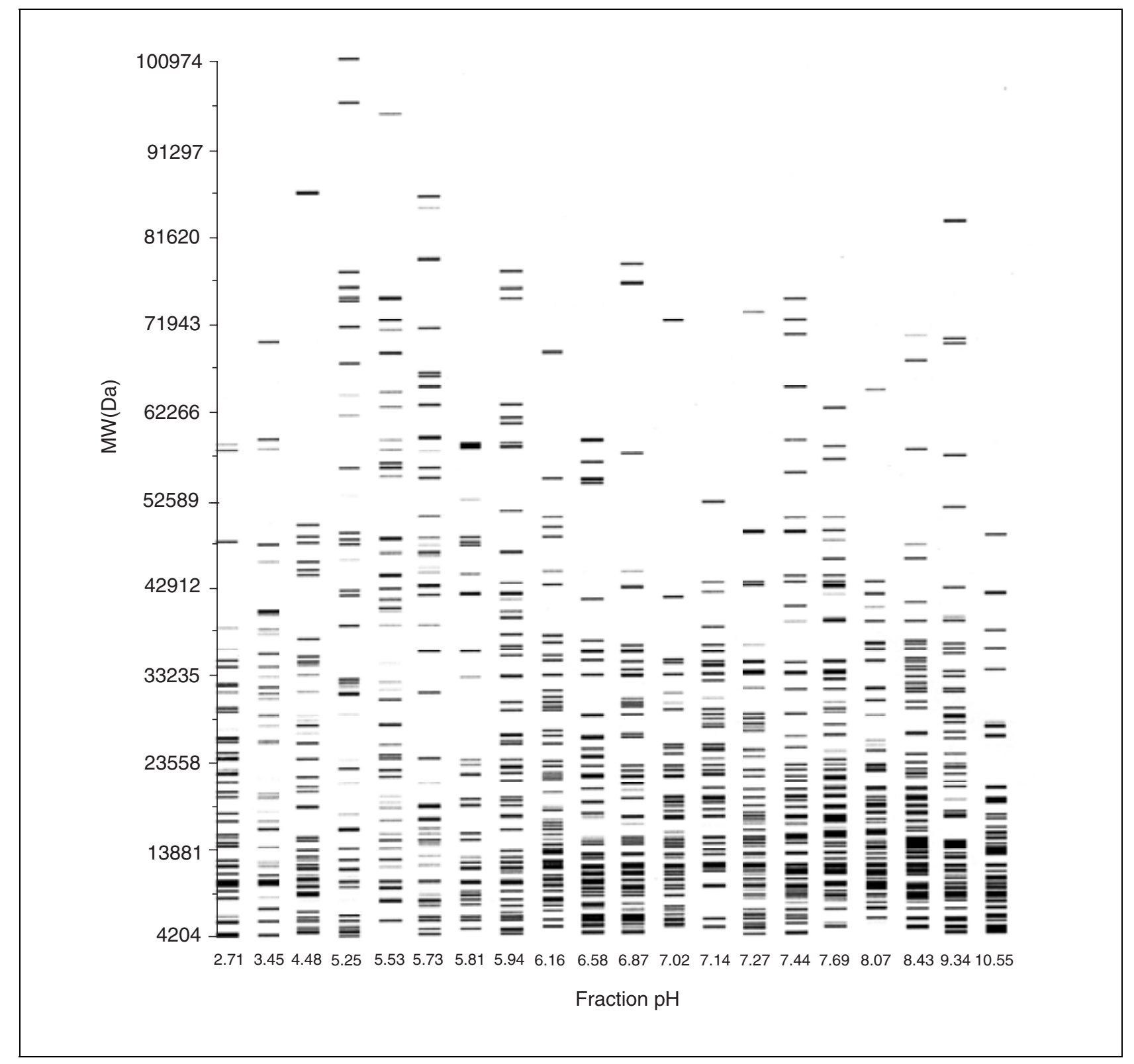

Figure 23.3.8 A complete two-dimensional mass map depicting MW versus pl of the MCF10A breast epithelial cell line. The $x$ axis shows measured pH values of each of 20 Rotofor fractions and the $y$ axis shows MW values from deconvoluted ESI-TOF-MS spectra.

\section{Materials}

Personal computer (speed $>200 \mathrm{MHz}$ )

MassLynx and MaxEnt (Micromass)

MSCombine (S. Parus, University of Michigan)

ProteoVue (Eprogen, Inc.)

\section{Data processing for one LC-MS run}

1. Combine mass spectra containing the same multiply charged peaks into one combined mass spectrum using MassLynx (Micromass).

One mass spectrum is acquired every second. For a protein eluting for 10 sec, 10 mass spectra should be combined into one spectrum.

Non-Gel-Based

Proteome Analysis

\subsubsection{9}

Supplement 34 


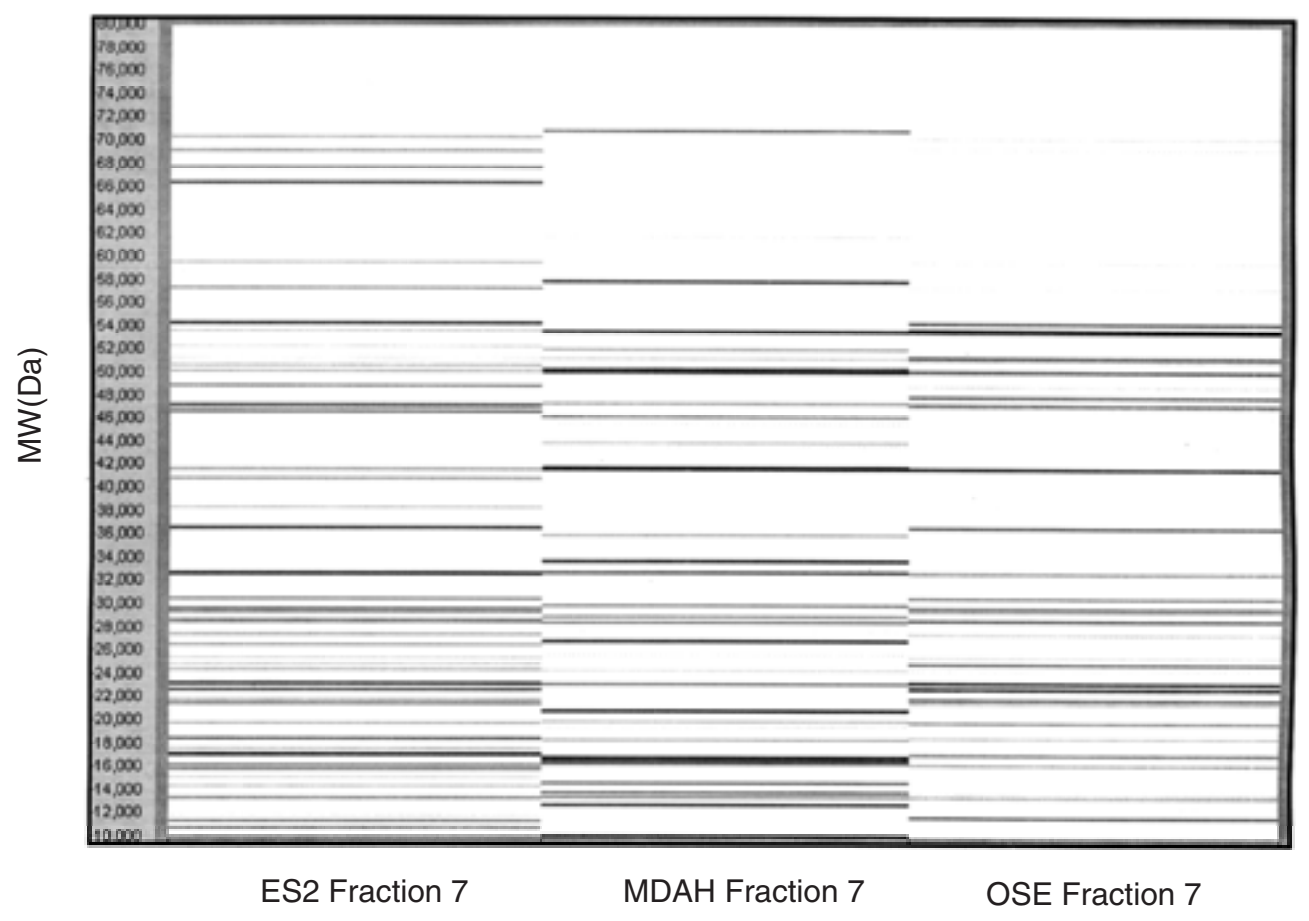

Figure 23.3.9 A two-dimensional mass map of MW versus pl comparing ES2, MDAH2774, and OSE ovarian cell lines for Rotofor fraction no. 7.

2-D Liquid

Separations of

Whole-Cell

Lysates

23.3.20

2. Still using MassLynx select the $\mathrm{m} / \mathrm{z}$ range in the combined mass spectrum for deconvolution by zooming to the selected $\mathrm{m} / \mathrm{z}$ range.

In the mass spectrum, peaks below 800 are usually considered to be noise. It will take more time to deconvolute a raw spectrum with wider $\mathrm{m} / \mathrm{z}$ range. Moreover, artifact peaks may appear in the deconvoluted spectrum.

3. Deconvolute the selected segment of spectrum with MaxEnt.

The deconvoluted spectrum is displayed as peak intensity versus $M W(D a)$.

4. Activate the "spectrum center function" in MassLynx, check the "areas" in the pop-up window for spectrum center, and perform center for the deconvoluted mass spectrum.

5. Zoom in to the protein peak and copy the MW value and peak area information into the MS Windows clipboard by using the "copy spectrum list" function in MassLynx. Paste into Notepad and save as a text file.

6. Repeat steps 1 to 5 through the LC-MS TIC (total ion count) chromatogram manually or using software if available.

7. Combine all text files into one combined text file with MSCombine.

8. Display the combined text file with ProteoVue.

This is one lane in a 2-D map. In order to obtain a 2-D map covering the entire target pH range, steps 1 to 8 should be repeated for each fraction in the range. 
REAGENTS AND SOLUTIONS

Use Milli-Q-purified water or equivalent for the preparation of all buffers. For common stock solutions, see APPENDIX 2E; for suppliers, see SUPPLIERS APPENDIX.

\section{CF elution buffer, $\mathrm{pH} 7$ to 4}

Place the following in a $250-\mathrm{ml}$ beaker:

$90.09 \mathrm{~g}$ urea

$25 \mathrm{ml}$ Polybuffer 74 (Amersham Pharmacia Biotech)

Ultrapure $\mathrm{H}_{2} \mathrm{O}$ to $\sim 210 \mathrm{ml}$

Stir at room temperature until completely dissolved. Degas under vacuum by sonication or by sparging with helium. Adjust $\mathrm{pH}$ to 4.0 by adding saturated iminodiacetic acid (the $\mathrm{pH}$ measurement should be performed at the same temperature as that of CF experiments). Add $500 \mathrm{mg}$ of $n$-octyl- $\beta$-D-glucopyranoside (OGL) and stir until dissolved. Transfer solution to 250-ml volumetric flask, rinse the beaker twice with water, and transfer to the flask. Add water to 250-ml mark. Mix well and store at $2^{\circ}$ to $4^{\circ} \mathrm{C}$ in the dark.

All solvents should be filtered through a 0.22- $\mu$ m nylon filter.

Final concentrations are: $10 \%$ (v/v) Polybuffer, 6 M urea, and 0.2\% (w/v) OGL.

\section{CF elution buffer, $\mathrm{pH} 8.5$ to 4}

Place the following in a $250-\mathrm{ml}$ beaker:

$90.09 \mathrm{~g}$ urea

$17.5 \mathrm{ml}$ Polybuffer 74 (Amersham Pharmacia Biotech)

$7.5 \mathrm{ml}$ Polybuffer 96 (Amersham Pharmacia Biotech)

Ultrapure $\mathrm{H}_{2} \mathrm{O}$ to $\sim 210 \mathrm{ml}$

Stir at room temperature until completely dissolved. Degas under vacuum by sonication or by sparging with helium. Adjust $\mathrm{pH}$ to 4.0 by adding saturated iminodiacetic acid. Add $500 \mathrm{mg}$ of $n$-octyl- $\beta$-D-glucopyranoside (OGL) and stir until dissolved. Transfer the solution to 250-ml volumetric flask, rinse the beaker twice with water, and transfer to the flask. Add water to 250-ml mark. Mix well and store at $2^{\circ}$ to $4^{\circ} \mathrm{C}$ in the dark.

All solvents should be filtered through a 0.22- $\mu$ m nylon filter.

Final concentrations are: $10 \%(v / v)$ Polybuffer, 6 M urea, and $0.2 \%(w / v) O G L$.

\section{CF start buffer, pH 7 to 4}

Place the following in a 500-ml beaker:

$180.18 \mathrm{~g}$ urea

$2.615 \mathrm{~g}$ Bis-Tris

Ultrapure $\mathrm{H}_{2} \mathrm{O}$ to $\sim 440 \mathrm{ml}$

Stir at room temperature until completely dissolved. Degas under vacuum by sonication or by sparging with helium. Adjust $\mathrm{pH}$ to 7.1 by adding saturated iminodiacetic acid. Add $1 \mathrm{~g} n$-octyl- $\beta$-D-glucopyranoside (OGL) and stir until dissolved. Transfer the solution to 500-ml volumetric flask, rinse the beaker twice with water, and transfer to the flask. Adjust with water to 500-ml mark. Mix well and store the solution at $2^{\circ}$ to $4^{\circ} \mathrm{C}$ in the dark.

All solvents should be filtered through a 0.22- $\mu$ m nylon filter.

Final concentrations are: $6 \mathrm{M}$ urea, $25 \mathrm{mM}$ Bis-Tris, and 0.2\% (w/v) OGL.

\section{CF start buffer, pH 8.5 to 4}

Place the following in a 500-ml beaker:

$180.18 \mathrm{~g}$ urea

$1.865 \mathrm{~g}$ triethanolamine (or $3.529 \mathrm{~g}$ Bis-Tris propane)

Ultrapure $\mathrm{H}_{2} \mathrm{O}$ to $\sim 440 \mathrm{ml}$.

Non-Gel-Based

Proteome Analysis

23.3.21 
Stir at room temperature until completely dissolved. Degas under vacuum, by sonication, or by sparging with helium. Adjust $\mathrm{pH}$ to 8.5 by adding saturated iminodiacetic acid. Add OGL and stir until dissolved. Transfer the solution to 500-ml volumetric flask, rinse the beaker twice with water, and transfer to the flask. Add water to $500-\mathrm{ml}$ mark. Mix well and store $2^{\circ}$ to $4^{\circ} \mathrm{C}$ in the dark.

All solvents should be filtered through a 0.22- $\mu$ m nylon filter.

Final concentrations are: $6 \mathrm{M}$ urea, $25 \mathrm{mM}$ Bis-Tris propane, and 0.2\% (w/v) OGL.

\section{General lysis buffer}

Place the following in a 100-ml beaker:

$22.52 \mathrm{~g}$ urea

$9.52 \mathrm{~g}$ thiourea

$0.304 \mathrm{~g}$ Tris hydrochloride

$1.25 \mathrm{~g} n$-octyl- $\beta$-D-glucopyranoside (OGL)

$0.0896 \mathrm{~g}$ TCEP

$1.868 \mathrm{ml}$ of $0.5 \mathrm{M}$ phenylmethylsulfonyl fluoride (PMSF) stock (prepared in DMSO or isopropanol)

$20 \mathrm{ml} 12.5 \%$ (v/v) glycerol

Stir at room temperature until completely dissolved. Transfer all of the solution to a $50-\mathrm{ml}$ volumetric flask. Add $12.5 \%$ (v/v) glycerol to the 50-ml mark. Dispense the above buffer solution into separate $2.0-\mathrm{ml}$ vials, then store them at $-20^{\circ} \mathrm{C}$.

Final concentrations are: $7.5 \mathrm{M}$ urea, $2.5 \mathrm{M}$ thiourea, $12.5 \%(\mathrm{v} / \mathrm{v})$ glycerol, $50 \mathrm{mM}$ Tris, $2.5 \%(w / v)$ n-octyl- $\beta$-D-glucopyranoside (OGL), $6.25 \mathrm{mM}$ Tris-(carboxyethyl)phosphine hydrochloride (TCEP), and 1.25 $\mathrm{mM}$ of PMSF.

Protease inhibitor cocktail from Sigma may also be used with mammalian cells; add $100 \mu \mathrm{l}$ of the cocktail solution per $100 \mathrm{ml}$ of lysis buffer, or to $1.25 \mathrm{mM}$ if the protease inhibitor cocktail molarity is known.

\section{Membrane lysis buffer $A$}

$50 \mathrm{mM}$ Tris. $\mathrm{Cl}, \mathrm{pH} 7.3$ (APPENDIX 2E)

$250 \mathrm{mM}$ sucrose

2 mM EDTA

$2 \mathrm{mM}$ phenylmethylsulfonyl fluoride (PMSF; add from 0.5 M stock in DMSO or isopropanol)

PMSF has a half-life in aqueous solution of $\sim 1 \mathrm{hr}$. Therefore, a stock solution of 0.5 M PMSF should be made in DMSO or isopropanol and should be added to the aqueous lysis solutions ( $50 \mathrm{mM}$ Tris. Cl and membrane lysis buffer A) to a final concentration of $0.5 \mathrm{mM}$ every hour.

\section{Membrane lysis buffer $B$}

$40 \mathrm{mM}$ Tris.Cl. $\mathrm{pH} 7.3$ (APPENDIX 2E)

$7 \mathrm{M}$ urea

$2 \mathrm{M}$ thiourea

$4 \%$ (w/v) $n$-octyl- $\beta$-D-glucopyranoside (OGL)

$2 \%(\mathrm{w} / \mathrm{v})$ CHAPS

$2 \%(\mathrm{w} / \mathrm{v}) \mathrm{N}$-decyl- $N, N$-dimethyl-3-ammonio-1-propane-sulfonate (SB3-10;

Eprogen)

$10 \mathrm{mM}$ TCEP (add from $0.5 \mathrm{M}$ stock solution; see recipe)

Store up to 1 month at $4^{\circ} \mathrm{C}$

\section{Rotofor running buffer}

A sample recipe is given below for a running buffer containing $1 \%$ ampholytes; the actual final ampholyte concentration that will be loaded in the Rotofor cell should match the protein concentration as detailed in Table 23.3.1. The volume of water in the recipe should be scaled up or down accordingly when both the volume of cell 
lysate and the volume of ampholyte are changed to match the total amount of proteins in the sample.

For $50 \mathrm{ml}$ running buffer: Place $18.018 \mathrm{~g}$ urea into $23.4 \mathrm{ml}$ distilled water (or other volume scaled according to amount of ampholyte added), stir until it dissolves; then add $7.612 \mathrm{~g}$ thiourea, $0.25 \mathrm{~g} n$-octyl- $\beta$-D-glucopyranoside (OGL), $5 \mathrm{ml}$ glycerol, 0.5 $\mathrm{ml}$ (or other volume to achieve appropriate ampholyte concentration; see Table 23.3.1) Bio-Lyte 3/10 ampholyte (Bio-Rad), and $200 \mu \mathrm{l} 0.5 \mathrm{M}$ tris(2-carboxyethyl)phosphine (TCEP) stock solution (see recipe). Store up to 1 month at $4^{\circ} \mathrm{C}$.

Since $1 \mathrm{~g}$ urea accounts for a volume of $0.75 \mathrm{ml}$ and $1 \mathrm{~g}$ thiourea a volume of $1 \mathrm{ml}$, this contribution to the final volume should be considered when preparing the buffer solution. Therefore, one should begin with no more than $23.4 \mathrm{ml}$ of distilled water, otherwise the final volume will exceed $50 \mathrm{ml}$, resulting in incorrect final concentrations of running buffer constituents. The dissolution of urea is an endothermic process. Heating the solution will speed the process. Thiourea itself has very low solubility; however, its solubility increases in urea solution. Because urea decomposes at high temperatures, keep the temperature below $50^{\circ} \mathrm{C}$. OGL is a nonionic detergent, which helps solubilize membrane proteins and phospholipids. $n$-octyl $\beta$-D-galactopyranoside, an isoform of octyl- $\beta$-D-glucopyranoside (OGL), is also a good nonionic detergent, but it is much more expensive than the glucopyranoside isoform.

Final concentrations are: $6 \mathrm{M}$ urea, $2 \mathrm{M}$ thiourea, $0.5 \%(\mathrm{w} / \mathrm{v})$ OGL, $1 \%(\mathrm{v} / \mathrm{v})$ ampholytes, $10 \%(\mathrm{v} / \mathrm{v})$ glycerol, and $2 \mathrm{mM}$ TCEP.

Gloves are required when handling chemicals. TCEP, thiourea, and OGL are harmful for ingestion, inhalation, and skin contact.

\section{TCEP stock solution, $0.5 \mathrm{M}$}

Dissolve $1.433 \mathrm{~g}$ tris(2-carboxyethyl)phosphine (TCEP) in $10 \mathrm{ml}$ distilled water.

TCEP should be handled in the hood with gloves. Inhalation, ingestion, or skin contact is harmful. Store at $4^{\circ} \mathrm{C}$ when not in use.

\section{COMMENTARY}

\section{Background Information}

Isoelectric focusing is a powerful technique in which proteins are focused to narrow bands under the influence of an electric field. A stable and uniform $\mathrm{pH}$ gradient, convection control, and $\mathrm{pH}$ measurement are three key factors for the success of any IEF method.

In the Rotofor, a stable $\mathrm{pH}$ gradient is established by carrier ampholytes, which are composed of synthetic polyamino-carboxylic acids or polyamino-sulfonic acids with molecular weights of 300 to 900 (Osterman, 1984). Under the influence of an electric field, these amphoteric molecules migrate to their respective $\mathrm{pI}$ values and a $\mathrm{pH}$ gradient with increasing $\mathrm{pH}$ from anode to cathode is created. The high buffering capacity and conductivity of ampholytes prevent the distortion of the $\mathrm{pH}$ gradient when charged proteins are present; consequently, a stable and uniform $\mathrm{pH}$ gradient is obtained in the liquid phase.

During the operation of the Rotofor, rotating the focusing chamber around the focusing axis counteracts convection. Increasing the viscosity of the running buffer can further control convection. In gel-based IEF, convection is prevented by the use of a solid gel support. Convection is more efficiently eliminated because liquid molecules are restricted from moving. However, sample recovery from gels is more difficult, considering that focused proteins must be removed from the gel support for further analysis. Using the Rotofor, the focused proteins are still in solution phase; therefore, it is easy to extract proteins from the device without remixing. In the authors' experience, the Mini-Rotofor chamber can fractionate $>50 \mathrm{mg}$ of proteins, and the standard Rotofor can fractionate gram-level samples. Compared to the maximum loadability of a gel, i.e., $\sim 5 \mathrm{mg}$, the Rotofor is at least 10 times higher. In addition, scale-up can be easily achieved by going from the mini-Rotofor to the preparative model, in which the volume of running solution is increased. These advantages of the Rotofor and the degree of fractionation achieved in the $\mathrm{pH}$
Non-Gel-Based Proteome Analysis

23.3.23 
dimension make it an excellent method for prefractionation of complex protein mixtures.

Since Bio-Rad released the Rotofor in the 1980s, it has been successfully used in isolating proteins from serum, cell cultures, tissues, and cerebrospinal fluid (Davidsson et al., 1999; Puchades et al., 1999; Wall et al., 2000; Davidsson et al., 2001; Gustafsson et al., 2001; Wall et al., 2001; Kachman et al., 2002). When coupled with other orthogonal techniques such as reversed-phase liquid chromatography and mass spectrometry, it can be used as an improved alternative to 2-D gel electrophoresis in profiling protein content in complex mixtures (Wall et al., 2000; Wall et al., 2001; Kachman et al., 2002; Wall et al., 2002; Wang et al., 2002). In the proteomic era, it will play an important role in sample preparation with its ability to enrich low-abundance proteins from complex biological mixtures.

\section{Critical Parameters}

The most critical aspects of running the Rotofor include protein solubilization during operation, salt concentration, and temperature control. Once these parameters are optimized, excellent fractionation in the $\mathrm{pH}$ dimension can be achieved.

The Rotofor has two different focusing chambers, standard and mini. The difference between them is sample volume and, consequently, the amount of sample that can be loaded. The standard Rotofor chamber holds 60 $\mathrm{ml}$ of solution containing milligrams to grams of total protein, while the mini-Rotofor can only hold $18 \mathrm{ml}$ of sample with micrograms to milligrams of total protein. As a result, each pI fraction obtained from the standard Rotofor is $\sim 3 \mathrm{ml}$, while each pI fraction is $800 \mu \mathrm{l}$ for the mini-Rotofor. In order to obtain the desired concentration of the focused protein, a protein assay (see UNIT 3.4) is necessary to determine the total protein loaded and the volume into which it should be dissolved.

In the Rotofor device, proteins are focused according to their pIs; however, the solubility of a protein reaches its minimum at the $\mathrm{pI}$ point. In order to prevent proteins from precipitating out of solution, it is necessary to break disulfide bonds as well as to disrupt protein-protein intramolecular interactions. Charged compounds would be a perfect choice to disrupt intramolecular interactions because they provide a hydrophobic microenvironment around protein molecules and electrostatic repulsion between molecules. Unfortunately, such charged compounds are not compatible with IEF, with NPSRP-HPLC separations, or with subsequent mass spectrometric analyses. Thus, nonionic chaotrope mixtures (e.g., urea and thiourea) and nonionic and/or zwitterionic detergents (e.g., octylglucoside) should be added to efficiently solubilize proteins (Rabilloud, 2000). The recommended chaotropes and detergents are listed in Table 23.3.3. The presence of protein disulfide bonds may also lead to aggregation and decrease in protein solubility. Disulfide bonds are disrupted by thiol compounds such as mercaptoethanol and dithiothreitol (DTT), and also by the nonthiol reducing compound tris(2-carboxyethyl)phosphine (TCEP). The latter compound is favored because it is an effective reagent with the added advantages of being less toxic and odorless.

The loading of concentrated sample into the Rotofor requires a high ampholyte concentration to maintain a linear $\mathrm{pH}$ over the $\mathrm{pH}$ range and to keep proteins soluble at their pIs. Sample quantification is necessary to determine the optimal ampholyte concentration for the separation (see Table 23.3.1). In some cases, the solubility of the protein of interest may rely on ionic strength; in these instances, the ampholyte concentration can be increased.

Table 23.3.3 Recommended Solubilizing Agents for the Rotofor System ${ }^{a}$

\begin{tabular}{llll}
\hline Nonionic detergents & $\begin{array}{l}\text { Zwitterionic } \\
\text { detergents }\end{array}$ & Reducing agents & Chaotropic agents \\
\hline $\begin{array}{l}0.1 \%-3.0 \%(\mathrm{w} / \mathrm{v}) \\
\text { digitonin }\end{array}$ & $\begin{array}{l}0.1 \%-3.0 \%(\mathrm{w} / \mathrm{v}) \\
\text { CHAPS }\end{array}$ & $5-20 \mathrm{mM} \mathrm{DTE}$ & $1.0-8.0 \mathrm{M}$ urea \\
$\begin{array}{l}0.1 \%-3.0 \%(\mathrm{w} / \mathrm{v}) \\
\text { octylglucoside }\end{array}$ & CHAPS & $5-20 \mathrm{mM} \mathrm{DTE}$ & $2 \mathrm{M}$ thiourea \\
$\begin{array}{l}0.1 \%-3.0 \%(\mathrm{v} / \mathrm{v}) \\
\text { Triton X-114 }\end{array}$ & $1-5 \mathrm{mM}$ 2-ME & $\begin{array}{l}0.1 \%-2.0 \%(\mathrm{w} / \mathrm{v}) \\
\text { glycine } \\
0.1 \%-2.0 \%(\mathrm{w} / \mathrm{v})\end{array}$ \\
& $2 \mathrm{mM} \mathrm{TCEP}$ & \begin{tabular}{l}
$0.1 \%$ proline \\
\hline
\end{tabular} \\
\hline
\end{tabular}

2-D Liquid

Separations of Whole-Cell Lysates

23.3.24

Supplement 34 
During the Rotofor separation process, the proteins at the focused zone tend to diffuse away because of the concentration gradient. This diffusion decreases the focusing effect and results in decreased resolution. If one considers that the diffusion rate is proportional to the temperature in solution, maintaining low temperature, hence low diffusion, is essential for improved resolution. In addition, many proteins, especially enzymes, are labile to temperature. Efficiently dissipating the heat generated during IEF is important to maintain the activity of proteins. Typically, in a Rotofor experiment, a water-cooling system (e.g., a closed-cycle chiller system) is connected with the sample chamber through a cooling finger. The temperature of the chiller should be set at the lowest temperature that prevents proteins from precipitating out of the running buffer This cooling improves both the resolution and the activity. In addition, the use of glycerol stabilizes the hydration shell around proteins, thus effectively solubilizing them. Furthermore, glycerol increases the viscosity of the sample solution, which results in less diffusion and improved resolution.

The resolving power of IEF is proportional to the square root of the voltage gradient. When separating a sample with a high salt content, the high conductance of running solution will decrease the effective voltage across the sample and narrow the linear portion of the $\mathrm{pH}$ gradient. In this case, dialysis should be performed to desalt the sample before the Rotofor separation. The ionic strength should be controlled within $10 \mathrm{mM}$.

\section{Troubleshooting}

\section{Rotofor}

Maintaining proteins in solution phase is essential for operation of the Rotofor. Typical solubilizing agents include chaotropes, detergents, and reducing agents. Chaotropes disrupt protein-protein interactions; detergents provide a hydrophobic environment for proteins; reducing agents such as DTT, TCEP, and mercaptoethanol disrupt disulfide bonds. Protein focusing in the Rotofor is an electrophoretic process where high salt concentrations in the running solution affect focusing and generate heat. Therefore, all reagents added should be nonionic. The recommended solubilizing reagents for the Rotofor system are shown in Table 23.3.3.

Air bubbles trapped in the Rotofor system can cause voltage fluctuations and an unstable
$\mathrm{pH}$ gradient. In the worst case, air bubbles may break the electrical connection. After the Rotofor cell is filled with sample solution and ampholytes, the whole assembly should be turned $180^{\circ}$ and tapped on both electrolyte chambers to remove possible air bubbles trapped between the membrane and the sample. Air bubbles tend to be a more significant problem in the case of the mini-Rotofor than in the preparative device.

In a successful Rotofor run, the $\mathrm{pH}$ gradient should be a linear curve in the middle fractions, as shown in Figure 23.3.2. If the ampholyte in the running buffer is insufficient, i.e., not enough buffer capacity, sample proteins can distort the $\mathrm{pH}$ gradient. This problem can be easily resolved by adding more ampholyte. Air bubbles and other contaminants in the system can be another source that results in distortion of the $\mathrm{pH}$ gradient. In addition, uneven sample harvesting of the Rotofor fractions after the separation will have the same result.

Phosphoric acid (0.1 M) and sodium hydroxide $(0.1 \mathrm{M})$ are recommended for the anode and cathode electrolyte, respectively. The diffusion of protons and hydroxide ions through the ion exchange membrane is inevitable in the focusing run, so that the first several channels maybe very acidic $(<3)$ and the last channels very basic $(>10)$. The result is that the $\mathrm{pH}$ gradient is distorted at both ends. One can improve the linearity of the $\mathrm{pH}$ gradient by using a solid-phase matrix, such as anion and cation exchange resins, at both ends.

In a normal Rotofor run, the running current increases at the beginning then decreases with time. If the anode and cathode are inadvertently reversed, the current will increase with time and no current decrease is observed.

Strong overlapping of proteins across pI lanes occurs if the Rotofor is overloaded or the sample becomes aggregated. A protein assay and an effective solubilizing solution are strongly recommended before the Rotofor run. Overlapping cannot be completely overcome without membrane separators between adjacent fractions. In order to minimize overlapping across lanes, prefractionated samples can be pooled and loaded onto the Rotofor cell for a second run. Additional ampholyte is not necessary since the prefractionated samples already contain ampholytes covering the $\mathrm{pH}$ range. Other separation techniques can also be applied to purify target proteins since the Rotofor provides samples that are sufficiently fractionated.
Non-Gel-Based Proteome Analysis

23.3.25

Supplement 34 


\section{NPS RP-HPLC interfaced to ESI-MS}

Band broadening, decreased retention time, tailing, and elevated pressure are usually observed for "dirty" columns. These may result from irreversible adsorption of proteins and accumulated impurities from samples and solvents. Column cleaning after each separation is required for reproducible separation and prolonged column lifetime. Flushing the column in the reverse direction with $100 \%$ organic solvent such as acetonitrile or isopropanol is an effective means of removing hydrophobic substances and strongly retained molecules on top of the column bed. At least $10 \mathrm{CV}$ of organic solvent should be applied, followed by running a blank gradient. The cleaning cycle should be repeated until no peaks are observed on the blank run. If the column pressure is irreversibly increased, sonicating the column frits in organic solvent may help. Microbiological growth can occur if the system and column are not handled correctly. When not in use, both system and column should be flushed and stored in $100 \%$ organic solvent.

\section{Anticipated Results}

\section{Rotofor}

A successful Rotofor separation concentrates proteins into a fraction with a $\mathrm{pH}$ that is the same as the $\mathrm{pI}$ of the protein. The $\mathrm{pH}$ distribution is linear and shallow in the middle $\mathrm{pH}$ range, as shown in Figure 23.3.2, but is distorted at the two ends because of the diffusion of hydronium and hydroxide ions from the anode and cathode to the chamber. The fractionation is reasonably clean in the mid-pH range if the separation is not overloaded. Overlapping of proteins over a $\mathrm{pH}$ range is common in complex samples and especially for highly abundant proteins. Additionally, fraction overlapping occurs at the high $\mathrm{pH}$ due to cathodic drift. Often refractionation with the Rotofor or with other separation techniques (such as NPSRP-HPLC) is performed to purify the proteins for further analysis.

\section{Chromatofocusing}

A successful chromatofocusing run fractionates proteins according to their pIs. Proteins with higher pIs elute off the column earlier in the gradient. If run properly, a reproducible linear $\mathrm{pH}$ gradient for a given start and elution $\mathrm{pH}$ can be observed (See Fig. 23.3.2). One can obtain excellent fractionation to $<0.1 \mathrm{pH}$ unit for complex mixtures of proteins. The total protein recovery over a range from $\mathrm{pH} 4.0$ to
8.5 including the subsequent salt gradient is usually greater than $80 \%$.

\section{NPS RP-HPLC interfaced to ESI-MS}

A successful NPS-RP-HPLC separation of a first-phase IEF or CF fraction can typically separate at least 100 protein peaks in a 30-min run. The proteins that elute are generally purified proteins free of salt; however, the proteins are denatured because of the denaturing RPHPLC conditions. Since MS has the capability to resolve coeluting proteins and RP-HPLC concentrates proteins into narrow bands, the combination of LC and MS provides high resolution and sensitivity. The method has excellent reproducibility for detection of specific proteins. ESI-MS detects the intact MW of protein with high accuracy. The recovery of total protein is generally higher in such liquid-based separation techniques as compared to 2-D gels. The recovery of most proteins under $100 \mathrm{kDa}$ from the NPS columns varies from $65 \%$ to $95 \%$ (Wall et al., 1999).

\section{Time Considerations}

\section{Rotofor}

It takes $\sim 45 \mathrm{~min}$ to set up the Rotofor. A Rotofor run takes 4 to $5 \mathrm{hr}$ for optimum separation of proteins across the $\mathrm{pH}$ range.Cleaning of the Rotofor device takes $\sim 1 \mathrm{hr}$.

\section{Chromatofocusing}

The time required for a $\mathrm{CF}$ experiment varies with the length of column, flow rate, complexity of the sample, and volume of sample. A higher flow rate makes the $\mathrm{pH}$ gradient steeper, resulting in a shorter run with lower $\mathrm{pH}$ resolution. At $0.2 \mathrm{ml} / \mathrm{min}$ elution using an HPCF $1 \mathrm{D}$ column, a typical separation takes $\sim 1 \mathrm{hr}$ to complete.

\section{NPS RP-HPLC interfaced to ESI-MS}

A single NPS-RP-HPLC separation generally takes from 10 to $30 \mathrm{~min}$. When coupled to the ESI-MS, a run time of $\sim 30 \mathrm{~min}$ is generally used. Cleaning the column after the separation may require $1 \mathrm{hr}$ or longer depending on the complexity of sample and the lifetime of the column. For a relatively new column and simple protein mixtures, it takes $\sim 1 \mathrm{hr}$ to clean the column; however, for an old column and complex samples, the authors recommend that the column be cleaned for $3 \mathrm{hr}$.
2-D Liquid

Separations of

Whole-Cell Lysates

23.3.26 


\section{Literature Cited}

Banks, J.F. and Gulcicek, E.E. 1997. Rapid peptide mapping by reversed-phase liquid chromatography on nonporous silica with on-line electrospray time of flight mass spectrometry. Anal. Chem. 69:3973-3978.

Barder, T.J., Wohlman, P.J., Thrall, C., and DuBois, P.D. 1997. Fast chromatography and nonporous silica. $L C-G C$ 15:918-926.

Cech, N.B. and Enke, C.G. 2001. Practical implications of some recent studies in electrospray ionization fundamentals. Mass Spectrom. Rev. 20:362-387.

Chen, H. and Horvath, C. 1995. High-speed highperformance liquid chromatography of peptides and proteins. J. Chromatogr. A 705:3-20.

Chong, B.E., Lubman, D.M., Rosenspire, A., and Miller, F.R. 1999. Protein profiles and identification of HPLC isolated proteins of cancer cell lines using MALDI-TOF MS. Rapid Commun. Mass Spectrom. 13:1808-1812.

Chong, B.E., Kim, J., Lubman, D.M., Tiedje, J.M., and Kathariou, S. 2000. Use of non-porous reversed-phase high-performance liquid chromatography for protein profiling and isolation of proteins induced by temperature variations for Siberian permafrost bacteria with identification by matrix-assisted laser desorption ionization time-of-flight mass spectrometry and capillary electrophoresis-electrospray ionization mass spectrometry. J. Chromatogr. B 748:167-177.

Chong, B.E., Yan, F., Lubman, D.M., and Miller, F.R. 2001. Chromatofocusing nonporous reversed-phase high-performance liquid chromatography/electrospray ionization time-of-flight mass spectrometry of proteins form human breast cancer whole cell lysates: A novel two-dimensional liquid chromatography/mass spectrometry method. Rapid Commun. Mass Spectrom. 15:291-296.

Davidsson, P., Westman, A., Puchades, M., Nilsson, C.L., and Blennow, K. 1999. Characterization of protein from human cerebrospinal fluid by a combination of preparative two-dimensional liquid-phase electrophoresis and matrix-assisted laser desorption/ionization time-of-flight mass spectrometry. Anal. Chem. 71:642-647.

Davidsson, P., Paulson, L., Hesse, C., Blennow, K., and Nilsson, C.L. 2001. Proteome studies of human cerebrospinal fluid and brain tissue using a preparative two-dimensional electrophoresis approach prior to mass spectrometry. Proteomics 1:444-452.

Fountoulakis, M., Langen, H., Gray, C., and Takacs, B. 1998. Enrichment and purification of proteins of Haemophilus influenzae by chromatofocusing. J. Chromatogr. A 806:279-291.

Gooding, K.M. and Regnier, F.M. 1990. HPLC of Biological Macromolecules: Methods and Applications. Marcel Dekker, New York.
Gustafsson, E., Thoren, K., Larsson, T., Davidsson, P., Karlsson, K., and Nilsson, C.L. 2001. Identification of proteins from Escherichia coli using two-dimensional semi-preparative electrophoresis and mass spectrometry. Rapid Commun. Mass Spectrom. 15:428-432.

Hanson, M., Unger, K.K., Mant, C.T., and Hodges, R.S. 1996. Optimization strategies in ultrafast reversed-phase chromatography of proteins. Trans. Anal. Chem. 15:102-110.

Hutchens, T.W. 1998. Chromatofocusing. In Protein Purification: Principles, High-Resolution Methods, and Application, 2nd ed. (J.C. Janson, L. Ryden, eds.) pp. 149-174. John Wiley \& Sons, New York.

Kachman, M.T., Wang, H., Schwartz, D.R., Cho, K.R., and Lubman, D.M. 2002. A 2-D liquid separations/mass mapping method for interlysate comparison of ovarian cancers. Anal. Chem. 74:1779-1791.

Kastner, M. 2000. Protein Liquid Chromatography. Elsevier, New York.

Lee, W.C. 1997. Protein separation using non-porous sorbents. J. Chromatogr. B 699:29-45.

Liu, Y.S. and Anderson, D.J. 1997. Gradient chromatofocusing high-performance liquid chromatography. 1. Practical aspects. J. Chromatogr. A 762:207-217.

Mehlis, B. and Kertscher, U. 1997. Liquid chromatography mass spectrometry of peptides of biological samples. Anal. Chim. Acta. 352:71-83.

Niessen, W.M.A. and Tinke, A.P. 1995. Liquid-chromatography mass-spectrometry: General principles and instrumentation. J. Chromatogr. A 703:37-57.

Nilsson, C.L., Puchades, M., Westman, A., Blennow, K., and Davidsson, P. 1999. Identification of proteins in human pleural exudate using twodimensional preparative liquid-phase electrophoresis and matrix-assisted laser desorption/ionization mass spectrometry. Electrophoresis 20:860-865.

Nilsson, C.L., Larsson, T., Gustafsson, E., Karlsson, K., and Davidsson, P. 2000. Identification of protein vaccine candidates from Helicobacter pylori using a preparative two-dimensional electrophoretic procedure and mass spectrometry. Anal. Chem. 72:2148-2153.

Osterman, L.A. 1984. Methods of Protein and Nucleic Acid Research. Springer-Verlag, New York.

Phamacia Biotech. 1985. FPLC Ion-Exchange and Chromatofocusing: Principles and Methods. Pharmacia Biotech AB, Uppsala, Sweden.

Puchades, M., Westman, A., Blennow, K., and Davidsson, P. 1999. Analysis of intact proteins from cerebrospinal fluid by matrix-assisted laser desorption/ionization mass spectrometry after two-dimensional liquid-phase electrophoresis. Rapid Commun. Mass Spectrom. 13:2450-2455.

Rabilloud, T. 2000. Proteome Research: Two-Dimensional Gel Electrophoresis and Identification Methods. Springer-Verlag, New York.
Non-Gel-Based Proteome Analysis 23.3.27

Supplement 34 
Scopes, R.K. 1994. Protein Purification: Principles and Practice, 3rd ed. Springer-Verlag, New York.

Sluyterman, L.A.A.E. and Elgersma, O. 1978. Chromatofocusing: Isoelectric-focusing on ionexchange columns. 1. General principles. $J$. Chromatogr. 150:17-30.

Sluyterman, L.A.A.E. and Wijdenes, J. 1978. Chromatofocusing: Isoelectric-focusing on ion-exchange columns. 2. Experimental verification. J. Chromatogr. 150:31-44.

Sluyterman, L.A.A.E. and Wijdenes, J. 1981a. Chromatofocusing. 3. The properties of a DEAE-agarose anion-exchanger and its suitability for protein separations. J. Chromatogr. 206:429-440.

Sluyterman, L.A.A.E. and Wijdenes, J. 1981b. Chromatofocusing. 4. Properties of an agarose polyethyleneimine ion-exchanger and its suitability for protein separations. J. Chromatogr. 206:441-447.

Strong, J.C. and Frey, D.D. 1997. Experimental and numerical studies of the chromatofocusing of dilute proteins using retained $\mathrm{pH}$ gradients formed on a strong- base anion-exchange column. J. Chromatogr. A 769:129-143.

Wall, D.B., Lubman, D.M., and Flynn, S.J. 1999. Rapid profiling of induced proteins in bacteria using MALDI-TOF mass spectrometric detection of nonporous RP HPLC-separated whole cell lysates. Anal. Chem. 71:3894-3900.

Wall, D.B., Kachman, M.T., Gong, S., Hinderer, R., Parus, S.J., Misek, D.E., Hanash, S.M., and Lubman, D.M. 2000. Isoelectric focusing nonporous RP HPLC: A two-dimensional liquid-phase separation method for mapping of cellular proteins with identification using MALDI-TOF mass spectrometry. Anal. Chem. 72:1099-1111.
Wall, D.B., Kachman, M.T., Gong, S., Parus, S.J., Long, M.W., and Lubman, D.M. 2001. Isoelectric focusing nonporous silica reversed-phase high-performance liquid chromatography/electrospray ionization time-of-flight mass spectrometry: a three-dimensional liquid-phase protein separation method as applied to the human erythroleukemia cell-line. Rapid Commun. Mass Spectrom. 15:1649-1661.

Wall, D.B., Parus, S.J., and Lubman, D.M. 2002. Three-dimensional protein map according to $\mathrm{pI}$, hydrophobicity and molecular mass. J. Chromatogr. B 774:53-58.

Wang, H., Kachman, M.T., Schwartz, D.R., Cho, K.R., and Lubman, D.M. 2002. A protein molecular weight map of ES2 clear cell ovarian carcinoma cells using a two-dimensional liquid separations/mass mapping technique. Electrophoresis 23:3168-3181.

Yang, Y.J. and Lee, M.L. 1999. Theoretical optimization of packed capillary column liquid chromatography using nonporous particles. J. Microcol. Sep. 11:131-140.

Yu, J. and El Rassi, Z. 1997. High performance liquid chromatography of small and large molecules with nonporous silica-based stationary phases. J. Liq. Chrom. Rel. Technol. 20:183-201.

Contributed by Kan Zhu, Fang Yan, Kimberly A. O’Neil, Rick Hamler, and David M. Lubman

The University of Michigan

Ann Arbor, Michigan

Linda Lin and Timothy J. Barder

Eprogen, Inc.

Darien, Illinois
2-D Liquid Separations of Whole-Cell Lysates 23.3.28 